Discussion Paper No. 10-080

\title{
Antitrust Immunity for Airline Alliances
}

Volodymyr Bilotkach and Kai Hüschelrath

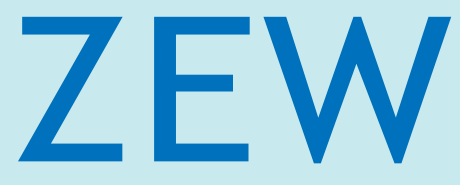

Zentrum für Europäische Wirtschaftsforschung $\mathrm{GmbH}$

Centre for European

Economic Research 


\section{Discussion Paper No. 10-080}

\section{Antitrust Immunity for Airline Alliances}

Volodymyr Bilotkach and Kai Hüschelrath

Download this ZEW Discussion Paper from our ftp server:

ftp://ftp.zew.de/pub/zew-docs/dp/dp10080.pdf

Die Discussion Papers dienen einer möglichst schnellen Verbreitung von neueren Forschungsarbeiten des ZEW. Die Beiträge liegen in alleiniger Verantwortung der Autoren und stellen nicht notwendigerweise die Meinung des ZEW dar.

Discussion Papers are intended to make results of ZEW research promptly available to other economists in order to encourage discussion and suggestions for revisions. The authors are solely responsible for the contents which do not necessarily represent the opinion of the ZEW. 


\section{Non-technical summary}

The market developments in international air transportation have led to the dominance of three global airline alliances - Star, SkyTeam and oneworld. At the same time, members of these alliances receive increasingly more freedom in coordinating various aspects of joint operations, including scheduling and pricing decisions as well as the right to form revenuesharing joint ventures in international markets. Although the significant consumer benefits generated by airline cooperation are undisputed, the recent developments raise antitrust concerns. Against this background, the paper aims at comparing the identified key competitive effects of airline alliances and antitrust immunity with the economic lines of reasoning in recent policy actions to develop recommendations for a full-fledged assessment of antitrust immunity for airline alliances.

Our conclusions are the following. First, the frequently postulated lower prices due to removal of double marginalization following antitrust immunity are not obvious from the theoretical point of view, and can be realized within a partnership without such immunity. However, the same conclusion might not be true for certain other types of immunity-specific efficiencies. Second, antitrust immunity might influence non-price characteristics of airline markets (with ex-ante ambiguous welfare effects). Third, antitrust immunity can inhibit individual partner airlines' network development, facilitate (tacit) collusion and lead to foreclosure of the interline markets for airlines from competing alliances. Fourth, approval conditions such as carve-outs have ambiguous welfare effects as they might keep up competition on overlapping routes but at the same time forecloses the realization of certain immunity-specific efficiencies. Fifth, while in the US the institutional structures behind antitrust immunity investigations should be reformed, the EU has to work on the internal procedures to speed up decision making. 


\section{Das Wichtigste in Kürze}

Die Marktentwicklungen im internationalen Luftverkehr haben zur Dominanz dreier großer und global agierender Allianzen von Fluggesellschaften geführt - Star, SkyTeam und oneworld. Parallel dazu wurden Mitgliedern dieser Allianzen mehr und mehr Freiheiten bei der Koordination verschiedener Betriebsabläufe zugestanden, wie beispielsweise im Bereich der Flugplanung oder Preissetzung aber auch im Hinblick auf das Recht, Erlösaufteilungen in internationalen Märkten vorzunehmen. Obwohl unstrittig ist, dass Kooperationen zwischen Fluggesellschaften signifikante Vorteile für die Konsumenten generieren, lösen die aktuell beobachtbaren Entwicklungen die Frage nach einer wettbewerbspolitischen Einschätzung aus. Vor diesem Hintergrund verfolgt der Aufsatz das Ziel, die identifizierten zentralen wettbewerblichen Effekte von Luftverkehrsallianzen und der Gewährung von AntitrustImmunität $\mathrm{zu}$ vergleichen mit den ökonomischen Argumentationslinien in jüngeren Entscheidungen der jeweils zuständigen Behörden. Aus diesem Vergleich lassen sich dann in der Folge Empfehlungen für eine vollständige Analyse der ökonomischen Wirkungen der Gewährung von Antitrust-Immunität ableiten.

Unsere Schlussfolgerungen sind die folgenden. Erstens, die vielfach postulierten niedrigeren Preise aufgrund des Wegfalls des doppelten Preisaufschlags in der Folge der Gewährung von Antitrust Immunität erscheinen aus theoretischer Sicht nicht offensichtlich und könnten auch durch Kooperationen ohne Antitrust-Immunität erzielt werden. Diese Schlussfolgerung mag allerdings nicht für andere Arten immunitätsspezifischer Effizienzvorteile zutreffen. Zweitens, Antitrust-Immunität kann einen Einfluss auf die nichtpreislichen Charakteristika von Luftverkehrsmärkten haben - mit ex-ante nicht eindeutigen Wohlfahrtswirkungen. Drittens, Antitrust-Immunität kann die Entwicklung der individuellen Netzwerke der Fluggesellschaften einschränken, kann kollusive Verhaltensweisen erleichtern und zu einer Abschottung der Interline-Märkte für allianzfremde Fluggesellschaften führen. Viertens, die bisher verwandten Auflagen wie beispielsweise ,carve-outs’ haben nicht eindeutige Wohlfahrtswirkungen da sie zwar einerseits Wettbewerb auf überlappenden Strecken erhalten aber gleichzeitig die Realisierung bestimmter immunitätsspezifischer Effizienzvorteile verhindern. Fünftens, während in den USA die institutionellen Strukturen hinter Untersuchungen von Antitrust-Immunität Reformbedarf erkennen lassen, sollte die EU an einer Beschleunigung der Entscheidungsfindungsprozesse arbeiten. 


\title{
ANTITRUST IMMUNITY FOR AIRLINE ALLIANCES
}

\author{
Volodymyr Bilotkach* \& Kai Hüschelrath $^{\S}$
}

\begin{abstract}
The market developments in international air transportation have led to the dominance of three global airline alliances - Star, SkyTeam and oneworld. At the same time, members of these alliances receive increasingly more freedom in coordinating various aspects of joint operations, including scheduling and pricing decisions, as well as the right to form revenue-sharing joint ventures in international markets. Although the significant consumer benefits generated by airline cooperation are undisputed, the recent developments raise antitrust concerns. Against this background, the paper compares the key competitive effects of airline alliances and antitrust immunity with the economic lines of reasoning in recent policy actions to develop recommendations for a full-fledged assessment of antitrust immunity for airline alliances.
\end{abstract}

JEL: L41, L93, K21

\section{INTRODUCTION}

Although the first airline partnership appeared in the 1930s, when Pan American-Grace Airways and parent company Pan American World Airways agreed to exchange routes to Latin America, the last ten to fifteen years witnessed a substantial increase in the scale and scope of airline alliances. In 2008, the three remaining world-wide airline alliances - Star, SkyTeam and oneworld - together transported about 75 percent of the roughly 1,865 million airline passengers world-wide. ${ }^{1}$ Airline alliances have particularly high market shares (at least $70 \%$, based on annual passenger volumes) on inter-continental markets, with the transatlantic market between North America and Europe being no exception.

Despite the significant increase in concentration among the global airline alliances, members of these partnerships receive increasingly more freedom in coordinating various aspects of joint operations, including scheduling and pricing decisions, as well as the right to form revenue-sharing joint ventures. Moreover, we observe a recent tendency towards awarding these freedoms - better known as antitrust immunity ${ }^{2}$ - to groups rather than pairs

\footnotetext{
Assistant Professor of Economics, University of California · Irvine, Department of Economics, 3151 Social Science Plaza, Irvine, CA 92697, USA, E-Mail: vbilotka@uci.edu. We started working on the paper while Bilotkach was a visiting researcher at ZEW. Bilotkach thanks ZEW for support and hospitality. Furthermore, we would like to thank Claudio Calcagno (European University Institute, Florence) and the editor, J. Gregory Sidak, for valuable comments on a draft version of the paper. The usual disclaimer applies.

$\S \quad$ Senior Researcher, ZEW Centre for European Economic Research, Department for Industrial Economics and International Management, P.O. Box 1034 43, D-68034 Mannheim, Germany, E-mail: hueschelrath@zew.de; Assistant Professor for Industrial Organization and Competitive Strategy, WHU Otto Beisheim School of Management, Burgplatz 2, 56179 Vallendar, Germany.

1 According to Star Alliance and SkyTeam web-sites.

2 Although we will use the term 'antitrust immunity' (which refers to US antitrust laws) throughout the paper, our general analysis is not restricted to the US but also applies to the European context. However, given the significant institutional and structural differences between the two jurisdictions, an application of the general analysis to individual cases might lead to partly different conclusions.
} 
of alliance member airlines. This development led to the emergence of an effective triopoly in international aviation, in particular in the transatlantic market, where revenue sharing joint ventures are currently implemented within SkyTeam and Star Alliance. These 'joint ventures' are operationally very close to mergers and only the regulatory constraints, most notably the foreign ownership restrictions on both sides of the Atlantic might prevent full mergers between alliance members.

Against this background, the paper compares the key competitive effects of airline alliances and antitrust immunity with the economic lines of reasoning in recent policy actions to develop recommendations for a full-fledged assessment of antitrust immunity for airline alliances. The paper is organized as follows. The second section gives a brief introduction into the general economics of airline alliances, complemented by an identification and discussion of the key competitive effects of antitrust immunity for airline alliances in the third section. Subsequently, a discussion of recent policy actions on both sides of the North Atlantic is provided. This is followed by a comparison of the relevant economic analysis with the identified policy issues, and the derivation of important conclusions for a full-fledged assessment of antitrust immunity for airline alliances.

\section{THE ECONOMICS OF AIRLINE ALLIANCES}

An important precondition for an analysis of the competitive effects of antitrust immunity for airline alliances is an understanding of the key business motivations and key economic effects of such agreements. Consequently, the following two sections briefly characterize both complexes from a theoretical and empirical perspective. It is important to note, however, that this section discusses the general benefits and costs of airline alliances and not the incremental benefits and costs of granting antitrust immunity. Such an analysis - which is at the heart of any elaborate thinking on antitrust immunity - is provided in the subsequent third section.

\subsection{Characterization of airline alliances}

The question of the determinants of firm boundaries has triggered an extensive discussion in economics and business strategy literature over the last couple of decades. As far as the horizontal boundaries are concerned, cost considerations are presumed to be one important determinant. With respect to the vertical boundaries, theoretical and empirical research has demonstrated the importance of the balance between investment incentives (specific assets) and performance incentives. ${ }^{3}$ As a consequence, both complexes together determine the efficient degree of cooperation; that is, the degree which minimizes the sum of production and transaction cost.

In addition to the two polar options of 'market' and 'integration', several hybrid organizational forms have emerged to reach the desired efficient solution for organizing economic activities. Strategic alliances and joint ventures can be interpreted as two available options for the optimization of a firm's horizontal and vertical organizational structure. Let us focus on joint ventures ${ }^{4}$ for the time being. They generally occur when two or more firms pool

\footnotetext{
See Luis Cabral, Introduction to Industrial Organization, (Cambridge: MIT Press 2000).

The business strategy literature does not provide a clear definition and delineation of strategic alliances and joint ventures. Jay Barney, Gaining and Sustaining Competitive Advantage, (New Jersey: Prentice Hall 2002), for example, subdivides 'strategic alliances' into non-equity alliances, equity alliances, and joint ventures. The key difference between the latter and the former two is that only a joint venture leads to the creation of a legally independent new corporation in which the parent companies hold shares. Following this delineation, airline alliances must typically be categorized as 'non-equity alliances' rather than 'joint ventures'. However, in the remainder of this paper we follow the majority of the literature and use the term 'joint venture' for airline alliances. In fact, both terms can be considered almost interchangeable, as both organizational forms are very similar in their motivations and economic effects. Furthermore, at least from a European competition law perspective, cooperation agreements between airlines can be viewed as joint
} 
some of their resources within a common legal organization. ${ }^{5}$ The theoretical rationales for forming joint ventures rather than entering into regular contracts include transaction costs savings, strategic behavior, and capitalizing on the organizational knowledge. The former of the three is well in line with the traditional Stiglerian boundaries of the firm argument; the second relates to longer-term profit maximization; and the latter views joint ventures as a means by which the firms learn or retain their capabilities. ${ }^{6}$

Shapiro and Willig ${ }^{7}$ point to the following potential benefits of joint ventures. First, joint ventures can be a mechanism for effective risk sharing in an uncertain environment. Second, they help the firms realize cost savings due to either the complementary nature of their products or economies of scale and scope. Furthermore, Barney ${ }^{8}$ reminds that joint ventures can be used as a vehicle to facilitate tacit collusion among the partner firms (in related markets), thereby increasing market power and profits. Additionally, joint ventures can help the firms to enter new markets, industries, or industry segments.

However, the potential benefits of such agreements have to be traded off against the potential costs. For example, when partners' goals differ, joint ventures may exacerbate the situation and hurt rather than help the parties involved. Also, Shapiro and Willig ${ }^{9}$ point to the potential for free riding by the venture partners as another possible problem associated with joint ventures. Furthermore, Walker ${ }^{10}$ identifies reduced control over decision making, strategic inflexibility, weaker organizational identity of the participating companies, and potential conflicts with antitrust law as additional disadvantages of cooperation among firms in general, and joint ventures in particular.

Turning from the brief general characterization of joint ventures to airline alliances, one may have the impression that joint ventures between airlines are a relatively new phenomenon. However, although alliances as we know them now have appeared and progressed in the age of airline industry deregulation, the regulated international airline industry has seen numerous revenue and capacity sharing deals written into the bilateral air service agreements - these can be interpreted as joint ventures according to the broad definition above. However, our focus will be on the arrangements which have appeared and persisted since the airlines have had some freedom to choose their strategies on the market.

Generally, the airline industry - defined here as commercial scheduled passenger transportation - deals with moving people and their luggage from point A to point $\mathrm{B}$. The production process is rather complex and involves many aspects such as ticketing, luggage handling, passenger catering, fueling, air traffic control, and aircraft maintenance. The airlines differ in many ways, from pricing policies, over the fleet mix to the degree to which they choose to vertically integrate the various parts of the production process. Yet, there is one thing in common for all the carriers: no single airline's network encompasses all possible 'point A to point B' combinations. This fact forces many passengers to 'interline' or change an airline during their journey.

Given these specifics of air transport, the first joint ventures between airlines on deregulated markets have appeared as a way to tackle this interlining problem more

ventures. For example, as reported by Richard Whish, Competition Law ( $^{\text {th }}$ edn., London: LexisNexis Butterworth 2003) 933, the alliance between Alitalia and KLM (Case No COMP/JV.19) was regarded by the Commission as a full-function joint venture, even though the companies did not create a corporate vehicle for their cooperation.

5 Bruce Kogut, Joint Ventures: Theoretical and Empirical Perspectives, 9 Strategic Management Journal 319 (1988).

6 Id.

7 Carl Shapiro \& Robert Willig, On the Antitrust Treatment of Production Joint Ventures, 4 Journal of Economic Perspectives 113 (1990).

8 Barney, see above $n 4$.

9 Shapiro \& Willig, see above $n 7$.

10 See Gordon Walker, Modern Competitive Strategy, (Boston: McGraw-Hill 2004). 
efficiently, making the 'joint' product more attractive to the customer as compared to other possible interlining options. At the perhaps most primitive level, the passenger would be more attracted to an interline service - other things equal and assuming no on-line service is available - which allows him/her to check the luggage through to the final destination, thus not having to worry about the checked bags beyond the customs requirements.

An advanced form of cooperation among airlines is called code-sharing. Code-sharing refers to including an airline's flights into the partner airlines' schedules. Thus, an airline via a code-sharing arrangement is able to enlarge its network without having to service additional flights. Moreover, it can sell tickets for the interline flight as its own. For this arrangement to work, however, the partner airlines need to set up a mechanism for placing the interline passengers on each other's flights. There are, roughly speaking, two such mechanisms. First, airline A can sell the ticket for the entire journey involving airlines A and B, and pay airline B a certain fee for accepting the interline passenger. Second, airline B can appropriate some of the seats on its flight for airline A to sell at the price it sees fit - a setup known as 'blocked space arrangement'. Doganis ${ }^{11}$ states that code-sharing agreements may or may not involve blocked space arrangements. Code-sharing related joint ventures are often complemented by agreements to jointly use airport facilities (e.g., gates). Additionally, sharing of customer loyalty (i.e., frequent flier) programs is very common.

A further degree of cooperation is reached if the alliance partners enter into some form of revenue sharing and joint price setting arrangements, which typically also imply a joint coordination of scheduling (i.e. departure times and flight frequencies). Although such partnerships are increasingly being referred to as 'joint ventures' in the literature and the business community, the discussion in this section shows that revenue sharing arrangements are only one of the many forms of cooperation among airlines. In fact, given the price fixing nature of such agreements, antitrust laws typically prohibit the implementation of this kind of joint venture, and granting antitrust immunity is a precondition for a legally sound implementation of such strategies. As a consequence, the remainder of the paper has to investigate the question why (antitrust) authorities nevertheless have allowed the airline alliances to enter into such agreements, and what kinds of competitive effects are potentially triggered by these decisions.

\subsection{Key economic effects of airline alliances}

A number of studies, both theoretical and empirical, evaluate the economic effects of international airline partnerships. Theoretical models of international airline consolidation include studies by Oum, Park and Zhang, ${ }^{12}$ Park, ${ }^{13}$ Brueckner, ${ }^{14}$ Brueckner and Whalen, ${ }^{15}$ Heimer and Shy, ${ }^{16}$ Bilotkach, ${ }^{17}$ Barla and Constantatos, ${ }^{18}$ Chen and Gayle ${ }^{19}$ and Flores-Fillol

11 Rigas Doganis, The Airline Business in the 21st Century, (London: Taylor \& Francis 2001).

12 Tae-Hoon Oum, Jong-Hun Park \& Anming Zhang, The Effects of Airline Codesharing Agreements on Firm Conduct and International Air Fares, 30 Journal of Transport Economics and Policy 187 (1996).

13 Jong-Hun Park, The Effect of Airline Alliances on Markets and Economic Welfare, 33 Transportation Research Part E 181 (1997).

14 Jan Brueckner, The Economics of International Codesharing: An Analysis of Airline Alliances, 19 International Journal of Industrial Organization 1475 (2001).

15 Jan Brueckner \& Tom Whalen, The Price Effects of International Airline Alliances, 43 Journal of Law and Economics 503 (2000).

16 Orit Heimer \& Oz Shy, 'Code-Sharing Agreements, Frequency of Flights, and Profits Under Parallel Operation', in Darin Lee (ed.), Advances in Airline Economics, Vol. 1: Competition Policy and Antitrust (Amsterdam: Elsevier 2006), 163-182.

17 Volodymyr Bilotkach, Price Competition between International Airline Alliances, 39 Journal of Transport Economics and Policy 167 (2005); Volodymyr Bilotkach, Complementary versus Semi-Complementary Airline Partnerships, 41 Transportation Research Part B, 381 (2007a); Volodymyr Bilotkach, Airline Partnerships and Schedule Coordination, 41 Journal of Transport Economics and Policy 413 (2007b). 
and Monquer-Colonques. ${ }^{20}$ Most of these studies analyze motives for and effects of a single airline alliance, outside of the broader context. ${ }^{21}$ Of the above cited papers, the issue of competition between alliances is considered by Brueckner and Whalen, ${ }^{22}$ Bilotkach, ${ }^{23}$ and Flores-Fillol and Monquer-Colonques. ${ }^{24}$ The general conclusion from those studies is that airline consolidation benefits interline passengers due to the complementary nature of the product and the removal of double marginalization. However, as soon as consolidation decreases competition, consumers may lose depending on the relative sizes of the cost-saving effect and the market power effect.

Generally, the size of the cost-saving effect is influenced to a great extent by the realized benefits of higher traffic due to cooperation between airlines reflected in economies of scope and economies of traffic density ${ }^{25}$ (i.e. falling average cost with higher load factors). Furthermore, airline alliances are expected to realize further alliance-specific efficiencies due to cost reductions via shared back office functions, maintenance facilities and operational staff, as well as joint marketing advantages of the integrated frequent flyer programs. These incremental advantages for consumers need to be traded off against the market power effect of airline consolidation. This effect is basically driven by the possibility that airline alliances might eliminate horizontal intra-alliance competition, thereby causing higher fares and a reduced choice on certain routes. ${ }^{26}$ The existence and magnitude of the market power effect is dependent on various competition parameters. For example, as argued by Oum et al. ${ }^{27}$ the degree of overlap between the respective networks is typically a key determinant because the higher the overlap, the more severe are the competition concerns, and the more likely are price increases as a consequence of cooperation. Furthermore, the participating airlines may use alliances to reduce competitive pressures by facilitating collusive behavior or restricting entry through the implementation of foreclosure strategies. ${ }^{28}$

Empirical analyses of the effects of international airline alliances have been offered by Oum et al.,29 Park and Zhang, ${ }^{30}$ Brueckner and Whalen, ${ }^{31}$ Brueckner, ${ }^{32}$ Whalen, ${ }^{33}$ and

18 Philippe Barla \& Christos Constantatos, On the Choice between Strategic Alliance and Merger in the Airline Sector: The Role of Strategic Effects, 40 Journal of Transport Economics and Policy 409 (2006).

19 Yongmin Chen \& Philip Gayle, Vertical Contracting Between Airlines: an Equilibrium Analysis of Codeshare Alliances, 25 International Journal of Industrial Organization 1046 (2007)

20 Ricardo Flores-Fillol \& Rafael Moner-Colonques, Strategic Formation of Airline Alliances, 41 Journal of Transport Economics and Policy 427 (2007).

21 Despite the various modeling approaches to airline alliances in recent years, most attempts in the literature frequently fail to differentiate between joint ventures and mergers between airlines. Alliances are also often found to be profitable for individual airlines. Sometimes such a conclusion comes with caveats: e.g., Bilotkach, 2005, see above n 17, as well as Flores-Fillol \& Monquer-Colonques, see id., suggest setups where alliance formation can be an outcome of a Prisoners' Dilemma type of setting, where each pair of potential partners is individually better off outside of an alliance, but can increase profits by forming a partnership, provided the other pair remains unallied.

22 Brueckner \& Whalen, see above n 15.

23 Bilotkach, 2005, see above n 17.

24 Flores-Fillol \& Monquer-Colonques, see above n 20.

25 For instance, Jan Brueckner \& Pablo Spiller, Economies of Traffic Density in the Deregulated Airline Industry, 37 Journal of Law and Economics 379 (1994) found that a $10 \%$ traffic increase lead to a $3.75 \%$ reduction in marginal costs.

26 James Reitzes \& Diana Moss, Airline Alliances and Systems Competition, 45 Houston Law Review 294 (2008).

27 Tae-Hoon Oum, Jong-Hun Park \& Anming Zhang, Globalization and Strategic Alliances: The Case of the Airline Industry, (London: Pergamon 2000) classify alliances into 'complementary' and 'parallel' ones. While complementary alliances - i.e. the networks of the alliance partners largely feed traffic to each other are likely to reduce fares, parallel alliances - i.e. the networks of the alliance partners partly overlap and competition on these routes is reduced - are likely to increase fares.

28 See Section III. below for a detailed assessment.

29 Oum et al., see above n 12. 
Bilotkach. ${ }^{34}{ }^{35}$ All of these papers confirm that airline alliances benefit interline passengers by offering lower fares. Park and Zhang also find evidence for increasing market power of the alliance members at their hubs, even though they suggest that this effect is offset by the cost savings that the alliance brings about. While finding that alliances decrease interline fares, Brueckner and Whalen ${ }^{36}$ fail to observe a statistically significant increase in fares due to airline consolidation where such appears to decrease the number of competitors.

In general, the consensus of research on the economic effects of airline alliances is that interline partnerships benefit consumers thanks to the removal of double marginalization, as well as through economies of scope and traffic density. These benefits might partly come in the form of lower ticket prices, but might also include higher flight frequency, more destinations within easy reach, or shorter travel times. All these factors tend to have a stimulating effect on demand and traffic growth. However, what need to be investigated closer in the following are the relative costs and benefits of several degrees of cooperation between airlines. In particular, an understanding needs to be developed of whether granting antitrust immunity is necessary to realize the key benefits for the consumers, or whether lower degrees of cooperation can reach comparable benefits levels (while avoiding the incremental costs). The following section will investigate this question in greater detail.

\section{COMPETITIVE EFFECTS OF ANTITRUST IMMUNITY FOR AIRLINE ALLIANCES}

Airline alliances were initially created to allow members to cross-sell each other's tickets. To this extent, there are no serious doubts that the effects of such agreements are procompetitive. On the one hand, such alliances bring obvious advantages for customers (e.g., easier connections and baggage transfers). On the other hand, no significant coordination of key competition parameters is facilitated by these agreements. Consequently, early alliances were largely cleared by the responsible authorities in the United States and the European Union. However, more recent alliances involved significantly higher degree of cooperation between the partners, and now include explicit coordination on capacities and fares, as well as sharing costs and revenues on transatlantic routes. Given the fact that such high degrees of cooperation among competitors - including key competition variables - typically either demand a merger or must be considered an illegal hard-core cartel, antitrust concerns are immediately raised. In particular, the key economic question which has to be investigated is whether antitrust immunity for airline alliances is necessary to realize the key benefits of airline cooperation or whether lower degrees of cooperation (such as code-sharing) are sufficient to reap those cooperation benefits. In order to provide an answer to this key question, the following section briefly characterizes the general significance of antitrust immunity, followed by a detailed assessment of its general effects on the key competition

30 Jong-Hun Park \& Anming Zhang, An Empirical Analysis of Global Airline Alliances: Cases in the North Atlantic Markets, 16 Review of Industrial Organization 367 (2000).

31 Brueckner \& Whalen, see above n 15.

32 Jan Brueckner, International Airfares in the Age of Alliances: The Effects of Codesharing and Antitrust Immunity, 85 Review of Economics and Statistics 105 (2003).

33 Tom Whalen, A Panel Data Analysis of Code Sharing, Antitrust Immunity and Open Skies Treaties in International Aviation Markets, 30 Review of Industrial Organization 39 (2007).

34 Volodymyr Bilotkach, Price Effects of Airline Consolidation: Evidence from a Sample of Transatlantic Markets, 33 Empirical Economics 427 (2007c).

35 There is also an older set of empirical papers examining the effects of airline alliances on airline costs, revenues or profits, passenger traffic, passenger fares, and convenience and service quality. However, given the significant changes in the degree of cooperation among airlines we omit a detailed discussion of the results here as they might not be that relevant for contemporary alliances. For overviews, see Kenneth Button \& Jonathan Drexler, The Implications on Economic Performance in Europe of Further Liberalization of the Transatlantic Air Market, 31 International Journal of Transport Economics 45 (2006) and S. Morrish \& R. Hamilton, Airline Alliances - Who Benefits?, 8 Journal of Air Transport Management 401 (2002).

36 Brueckner \& Whalen, see above n 15. 
parameters. Subsequently, specific theories of anticompetitive effects of antitrust immunity are discussed. These theories basically develop specific lines of reasoning how antitrust immunity can cause negative (consumer) welfare effects in the medium- and long-run.

\subsection{The general significance of airline alliances and antitrust immunity}

Airline partnerships in their modern form started appearing in the early 1990s, with airlines coordinating their handling of interline passengers via agreements of various types. As mentioned in the previous section, the most common and policy relevant form of such agreements involves code-sharing, whereby flights are assigned the partner airlines' flight number(s) and are effectively incorporated into those carriers' networks. Such services are oftentimes jointly marketed by the partner airlines, and are sometimes supplemented with blocked-space arrangements, whereby a certain number of seats on the flight are sold directly by the partner airline. Multi-airline code-sharing agreements led to the emergence of the global airline alliances, each of which started from the partnership between a US and an EU carrier. Oneworld developed around the partnership between American Airlines and British Airways; Skyteam evolved from the Delta Air Lines - Air France alliance; and the current Star Alliance is the expanded United Airlines - Lufthansa partnership. Some commentators explain the appearance and persistence of airline alliances with the impossibility of transatlantic mergers in combination with the (partially removed but still relevant) regulation of international markets. ${ }^{37}$

The recent general consolidation process among global airline alliances is also reflected in the aggregated concentration statistics for the transatlantic sub-market. Following the analysis of $\operatorname{Horan}^{38}$, the $\mathrm{CR}_{3}$ for the entire North-Atlantic market increased from 51\% in 1995 to 98\% in 2009. While in 1995, 13 independent carriers with a market share of at least $2 \%$ were operating in the North-Atlantic market, this number reduced to three in 2009. However, although these numbers - on the surface - suggest a dramatic consolidation process, its actual effect on the intensity of competition is undetermined. In addition to the general limitations of an analysis of aggregated data (in contrast to a detailed route-specific analysis ${ }^{39}$ ), especially the recent EU-US Open Aviation Area agreement and the thereby increased possibilities for market entry forecloses the immediate conclusion that competition intensity has generally decreased as a consequence of increased consolidation. Quite to the contrary, following the general idea of potential competition, the price setting power of alliances might be restricted sufficiently due to the removal of structural entry barriers through deregulation of international airline markets and the credible threat of entry created thereby. ${ }^{40}$

37 See Section IV. below for a detailed discussion.

38 Hubert Horan, Airline Consolidation, available at http://lawprofessors.typepad.com/aviation/2009/07 (visited 25th April 2010).

39 Based on the T-100 dataset for international airlines services (see n 41 below for a description), Alexander Cosmas, Evolution of Transatlantic Competition \& Air Transportation Regulatory Liberalization, (Presentation given at the MIT on 6 November 2008, Cambridge) investigates the aggregate change in transatlantic market competitiveness by monitoring the changes in the number of competitors on non-stop transatlantic routes between the periods 2000 to 2004, and 2004 to 2007. He finds that the overall number of non-stop markets increased from 217 to 233 . Focusing on the latter period, there has been no change in the number of competitors in about $60 \%$ of all non-stop markets, while about $9 \%$ experienced a decline, and the remaining $31 \%$ an increase in the number of competitors. Interestingly, the former period (2000 to 2004) showed a much more significant increase in the share of non-stop markets with a reduction in the number of competitors (about 27\%) and a much smaller increase in the non-stop markets which experienced an increase in the number of competitors (about 15\%). Admittedly, one of the important players on the transatlantic market (TWA) ceased to exist in 2001. Cosmas concludes from this analysis that competition in the transatlantic market has been increasing in aggregate since 2000.

40 However, although entry possibilities have increased in theory in the Open Aviation Area era, it remains unclear whether other (structural and/or strategic) entry barriers are sufficiently high to reduce or even eliminate entry threats. Generally, long-haul markets have economic characteristics which differ to a great extent from medium or short-haul markets. As characterized in greater detail by Horan, see above $n$ 38, the 
In the same way that the concentration process as such cannot be categorized as either proor anti-competitive without a detailed assessment, an immediate judgment on the social desirability of antitrust immunity must be considered premature. However, given the fact that pricing rivalry is typically considered as the hallmark of competition, granting antitrust immunity to partner airlines and thereby granting them the right to jointly set fares throughout their international networks as well as to establish revenue-sharing agreements needs a detailed and convincing economic justification. In order to give an indication of the importance of antitrust immunity on the transatlantic market, Figure 1 provides an overview of the market shares of non-stop transatlantic services involving hubs of alliances with antitrust immunity between 1996 and 2008.

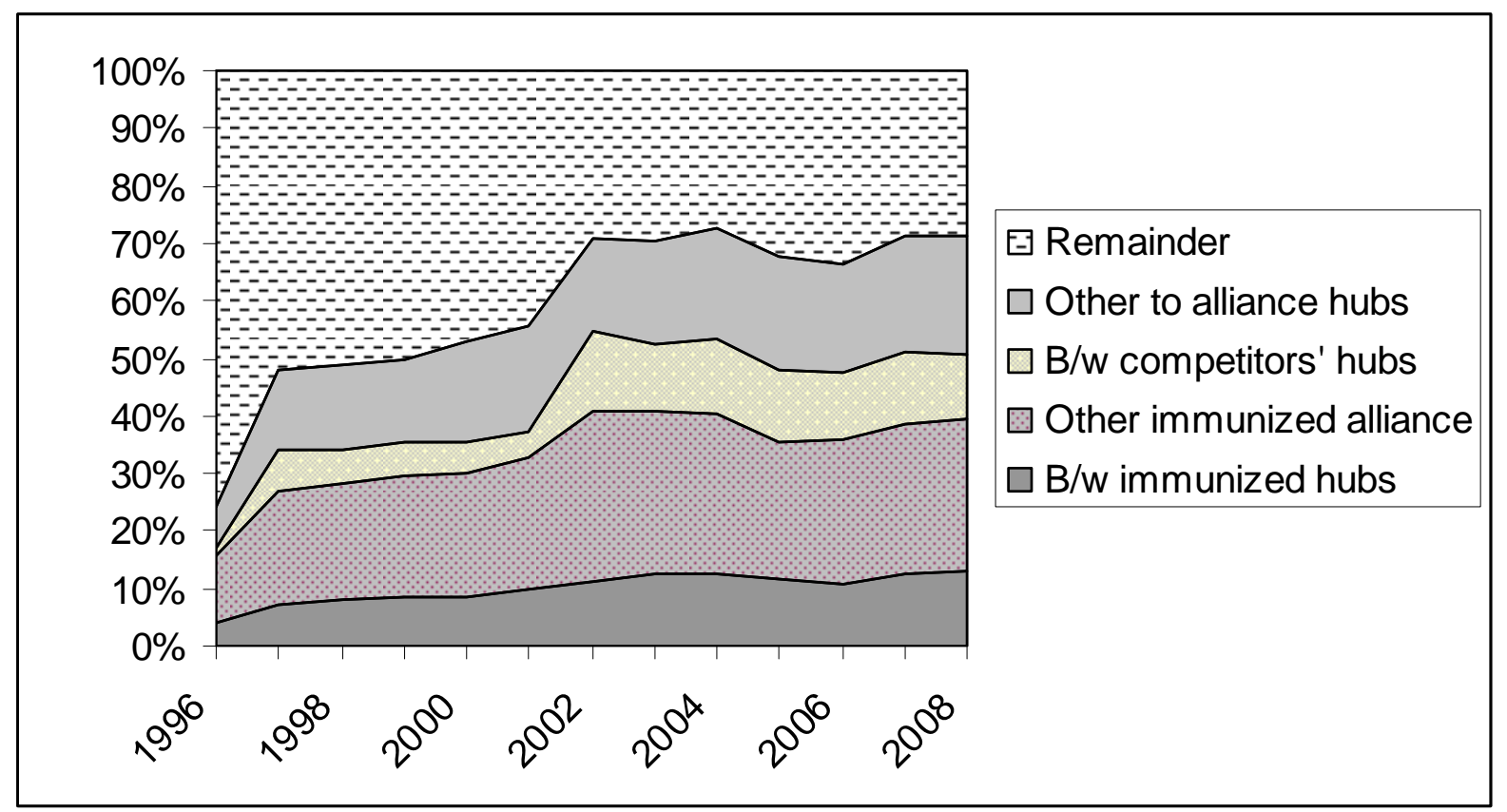

Figure 1. Market share of services involving hubs of alliances with immunity

Note: Market shares are based on frequency of service; shares based on number of passengers carried and seats offered are similar. ${ }^{41}$

significant scale requirements reflected in the need for large connecting hubs, global marketing capabilities or expensive long-haul aircraft are complemented by regulatory issues which partly remain in place even after the implementation of the US-EU Open Aviation Area agreement. The difficulty of entry in intercontinental markets can be seen in the fact that despite the significant increase in global trade and travel, the last decades only saw one entrant (USAirways) that gained a market share above 2 percent. Furthermore, the capacity restrictions at many hubs and the missing competition by low-cost carriers in this market segment are other arguments to conclude that the entry barriers in such markets are quite significant.

41 The graph is based on data from the T-100 dataset for international airline services of the US Department of Transportation. This dataset includes monthly information on all non-stop services between the US and the rest of the world. Each entry contains information about the segment's endpoints, operating carrier and monthly totals for the number of departures performed, seats offered, and passengers carried on this particular segment. Out of this dataset we have selected the data for travel between the US and all current EU members, plus Switzerland and Norway, for the years 1992 through 2008. We have retained only passenger services, and eliminated the services with fewer than ten departures performed over the given month. 
In Figure 1, four different types of airline services ${ }^{42}$ are defined according to an airline's membership in an alliance with antitrust immunity and the endpoints' status as a hub in one or the other airline's network. These four categories combined encompass (in 2008) almost 70 percent of all non-stop services in the dataset. This means that seven out of ten flights on the transatlantic (US-EU plus Norway and Switzerland) markets involve at least one airport used as a hub by the airline participating in a partnership with antitrust immunity. Furthermore, almost a quarter of all flights are between immunized alliances hubs, either within a single or between competing alliances. It can therefore be concluded that antitrust immunity is not a minor issue in the transatlantic market, but surely has the potential to influence the market structure, market conduct and market performance significantly.

As a consequence, the following sections address the most relevant building blocks of a comprehensive assessment of the economic effects of antitrust immunity from a largely theoretical perspective, accompanied with empirical evidence whenever available. In particular, the effects of antitrust immunity on prices and non-price parameters are investigated, complemented by a detailed look at specific theories of anticompetitive effects of antitrust immunity, such as the potential for market foreclosure or collusion.

\subsection{General effects on key competition parameters}

Generally, an assessment of the competitive effects of a certain business strategy requires a detailed assessment of the effects on key competition parameters in the respective industry. Although the effects on market price and market output are typically of the greatest concern, non-price parameters cannot be ruled out of from such an assessment. Consequently, the following sections will discuss both types of effects for airline alliances with antitrust immunity.

\subsubsection{Effects on market price}

The most imminent effect of airline alliances is the effect on market price. The basic line of reasoning found in the literature is that cooperation between airlines, given the complementary nature of the product, removes double marginalization, thereby reducing the price for the interline trip as compared to the no cooperation scenario. The double marginalization argument has also been used as a rationale for antitrust immunity, which involves allowing the alliance partners to jointly set the price for the interline trips. Additionally, any benefits of higher traffic due to cooperation between airlines are enhanced through economies of scope and traffic density. In the following, the effects of different degrees of cooperation on the market price are studied in two types of airline networks: a simple complementary airline network, and a simple partially overlapping network.

\subsubsection{Benefits and costs of cooperation in a complementary airline network}

Starting from a simple airline network, it is straightforward to see how moving from no cooperation to full cooperation creates benefits for both firms and consumers. Suppose

42 The four different types of airline services are the following:

- Immunized alliance members’ services between their respective hub airports (e.g., KLM flight from Amsterdam to Detroit); the short name we use for this category is 'Services between immunized hubs'

- Immunized alliance members' services from their hub airports to hub airport of competing alliance with antitrust immunity (e.g., KLM service from Amsterdam to Chicago O'Hare); the short name is 'Services between competitors' hubs'

- Immunized alliance members' services from their hub airports to airports which do not serve as hubs for any immunized alliance member (e.g., KLM service from Amsterdam to Boston); we refer to those as 'Other immunized alliance services'

- Services to immunized alliance members' hub airports by airlines which are themselves not immunized alliance members (e.g., British Airways services to such airports as Chicago O’Hare, Denver, Washington Dulles, etc.). This category is called 'Other services to alliance hubs'. 
airlines $A$ and $B$ provide complementary services on market $A B$, where no on-line travel is possible, as shown in Figure 2.

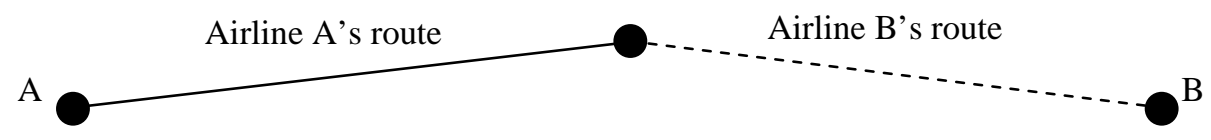

Figure 2. Simple complementary airline network

Assume demand for the joint product is given by $q=Q-p$; and each airline bears the cost of $c$ for its respective part of the service (we thus abstract from economies of scale or density). It is then a textbook result that without the cooperation each airline sets the sub-fare at $\frac{1}{3}(Q+C)$, so that the total fare is twice that amount, whereas with full coordination the total fare is $\frac{1}{2}(Q+c)$. Moreover, not only are consumers paying a lower price, but also the firms are making a higher profit. Removing double marginalization benefits everyone involved.

The above argument would work just as well in the case of a complete merger instead of the immunized alliance. The flaw in applying the above double marginalization argument to justify granting of the antitrust immunity lies in the fact that while we can potentially treat the case of partnership with antitrust immunity in the same way as we would treat the merger (especially in the case of a joint venture that involves revenue sharing); it is not correct to treat code-sharing without antitrust immunity as the case of no cooperation. Let us actually suggest a model of code-sharing without immunity, supposing airline A sets the price for the entire interline trip, transferring some of the total to airline $B$ as the payment for the interline passenger. Assume that airline A is the only one selling tickets for the interline journey. Let the price set by A for such tickets be $p$; and denote via $t_{B}$ the interline fee that airline A pays to $\mathrm{B}$. In this case, given our previous assumptions about demand and cost, the airlines' profit functions can be written as:

$$
\begin{aligned}
& \pi_{A}=\left(p-c-t_{B}\right)(Q-p) \\
& \pi_{B}=\left(t_{B}-c\right)(Q-p)
\end{aligned}
$$

Suppose - as we have effectively been doing up to now - that the two airlines make their decisions simultaneously. We then notice that firm B's profit function is increasing in this airline's decision variable, so that the game cannot be solved using regular first-order conditions.

Let us slightly complicate the setup, bringing it more in line with reality. Suppose airline A sells interline tickets for travel originating at point A, and carrier B only sells tickets for travel originating at point $\mathrm{B}$. Assume demands in both countries are symmetric and denote via $p_{A}$, $p_{B}, t_{A}$, and $t_{B}$ the respective interline fares and fees. The profit functions will in this case be written as:

$$
\begin{aligned}
& \pi_{A}=\left(p_{A}-c-t_{B}\right)\left(Q-p_{A}\right)+\left(t_{A}-c\right)\left(Q-p_{B}\right) \\
& \pi_{B}=\left(p_{B}-c-t_{A}\right)\left(Q-p_{B}\right)+\left(t_{B}-c\right)\left(Q-p_{A}\right)
\end{aligned}
$$

It is straightforward to show that the airlines' total profit will be maximized if both carriers set their interline fees at cost. Then, the airlines will be able to act as a vertically integrated monopolist on the respective market. However, setting the interline fees at cost is not a part of the Nash equilibrium in this setup, when the game is played only once. The catch is similar to the prisoners' dilemma: it is individually rational for each carrier to raise its $t$ above $c$ if the other carrier sets its $t$ at $c$. Yet, in a classical infinitely repeated interaction model the airlines will be able to sustain $t_{A}=t_{B}=c$ as part of the equilibrium in trigger strategies (with defection leading to no coordination indefinitely), provided they are patient enough. In this 
case, the total interline fares a customer will face will be the same as when the airlines are allowed to set them jointly. Thus, it is not inconceivable to suggest that code-sharing with or without antitrust immunity may lead to equivalent pricing outcomes, even though the argument is admittedly much clearer and simpler for the case with immunity.

We can also work out a setup under which effects of blocked space arrangements will be the same with and without the antitrust immunity. Again, suppose airline A sells all tickets for travel originating at A and airline B is an effective monopolist for point B originating travel. Then, if both carriers appropriate as many seats for interline passengers on their flights as the number of seats the partner chooses to sell (setting aside capacity constraints), the outcome will be the same as when the carriers cooperate in setting quantities (or prices, for that matter, as we are dealing with a single market).

We therefore have shown that antitrust immunity might not bring additional benefits to both firms and consumers even within a monopoly alliance. Note that Bilotkach ${ }^{43}$ has come to the same conclusion analyzing competition between airline alliances. We must, however, admit that in general the argument for benefits of a fully immunized alliance is more appealing, as it invokes the well known result of removal of double marginalization given the possibilities for joint fare setting following vertical integration. Furthermore, it must be mentioned in this respect that the argument above only refers to the removal of double marginalization, leaving possible additional cost efficiencies triggered by antitrust immunity (but not by simple code-sharing agreements) yet to be evaluated. ${ }^{44}$ In addition, Bilotkach ${ }^{45}$ shows that immunized alliances bring benefits to consumers via better scheduling coordination. All these parameters need to be included in an overall assessment of antitrust immunity for airline alliances.

\subsubsection{Benefits and costs of cooperation in a partially overlapping airline network}

Let us now introduce a more realistic airline network in which the routes partially overlap. The simplest form of such a network is sketched below.

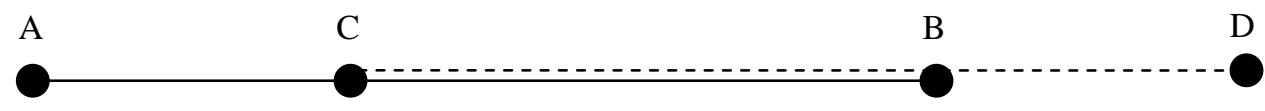

Figure 3. Simple partially overlapping airline network

As shown in Figure 3, the two potential alliance members have an overlapping route CB in their networks, connecting their hub airports. Obviously, allowing coordination between the partner airlines eliminates competition on the overlapping route, while bringing the identified benefits to interline passengers. In his seminal theoretical paper, Brueckner ${ }^{46}$ investigates the relative sizes of the two effects and finds - although the welfare impact on consumers is generally ambiguous - that the welfare increase in the interline markets are likely to offset the potential negative effects in non-stop markets.

Although this theoretical result suggests likely positive welfare effects of airline coordination in a partially overlapping network, a better option would be to keep the benefits of cooperation while avoiding the elimination of competition on the overlapping routes. As indicated above, competition is only eliminated if full coordination is allowed (i.e., antitrust immunity is granted) and as we have shown above, the benefits to interline passengers may or

\footnotetext{
43 Bilotkach, 2005, see above $n 17$.

44 Examples for such further alliance-specific efficiencies could be cost reductions via shared back office functions, maintenance facilities and operational staff as well as joint purchasing advantages.

45 Bilotkach, 2007b, see above n 17.

46 Brueckner, see above n 14.
} 
may not require antitrust immunity. ${ }^{47}$ In general, a regulator concerned about reduced competitive interaction on the overlapping part of the airlines' networks following a cooperative agreement by the airlines basically has three options. First, antitrust immunity to the partnership can be denied. Second, antitrust immunity can be granted anyway (as the benefits are expected to dwarf the costs) and third, antitrust immunity can be granted, but made applicable only to joint setting of the interline fares. The latter scheme is known as carve out setup, as routes within the overlapping part of the alliance partners' network are 'carved out' of the deal.

On the surface, carve outs appear to be an attractive option and, in fact, they have been used quite frequently by authorities on both sides of the Atlantic as approval conditions in immunity decisions. ${ }^{48}$ However, recent theoretical research by Brueckner and Proost ${ }^{49}$ shows that carve outs may yield lower welfare than simple immunized alliances where airline partners set up a revenue sharing agreement. The difference between the non-immunized alliance and the revenue sharing partnership is effectively that with the latter partner airlines enjoy more freedom over the cost side of their operations. This basically suggests that the real issue in point is whether joint operation of the alliance partners brings higher benefits via cost synergies and economies of density on the overlapping part of the network relative to the cost it may impose via increased market concentration and joint price-setting.

From an empirical perspective, Brueckner's ${ }^{50}$ research shows that antitrust immunity decreases fares for interline trips to a greater extent than code-sharing without such immunity. Whalen ${ }^{51}$ confirms these findings in a time-series analysis of the effects of international airline partnerships. In contrast, Bilotkach ${ }^{52}$ suggests, admittedly by analyzing a smaller sample of routes than Brueckner ${ }^{53}$, that antitrust immunity does not decrease fares by more than consolidation via code-sharing already does. Additionally, an empirical study by Wan, Zou and Dresner ${ }^{54}$ find that cost synergies are large enough on parallel routes to avoid price increases as a consequence of joint price-setting. Interestingly, they find that oneworld business class fares are lower than comparable fares between non-alliance hubs. Given the fact that oneworld did not have antitrust immunity to coordinate fares, this result can be interpreted to imply that alliances without antitrust immunity may produce the greatest consumer benefits. Most recently, an econometric study by Willig, Israel and Keating ${ }^{55}$ challenged the results of a DOJ study on the price effects of antitrust immunity. Contrary to the results of the DOJ, the authors are unable to find - across a range of model variations any evidence that antitrust immunity causes an increase in fares on gateway-to-gateway routes. ${ }^{56}$ Part of the explanation most likely relates to the incentives to expand capacity on

47 Given the obvious benefits of cooperation for interline passengers, we do not consider a prohibition of codesharing as an attractive option.

48 See Section IV. below.

49 Jan Brueckner \& Stef Proos, Carve-Outs under Airline Antitrust Immunity, forthcoming International Journal of Industrial Organization (2010)

50 Brueckner, see above n 14.

51 Whalen, see above $\mathrm{n} 33$.

52 Bilotkach, 2007c, see above $n 34$.

53 Brueckner, see above n 14.

54 Xiang Wan, Li Zou \& Martin Dresner, Assessing the Price Effect of Airline Alliances on Parallel Routes, 45 Transportation Research Part E 627 (2009).

55 Robert Willig, Mark Israel \& Bryan Keating, Competitive Effects of Airline Antitrust Immunity, (Working Paper 2009).

56 Rene Kamita, Analyzing the Effects of Temporary Antitrust Immunity: The Aloha-Hawaiian Immunity Agreement, (Working Paper 2008) analyzes the effects of temporary antitrust immunity granted to Aloha Airlines and Hawaiian Airlines for inter-island Hawaiian traffic from December 2002 to October 2003. He not only finds that prices increased significantly during the period of coordination but also that they remained at an elevated level until the entry of a new competitor. Although admittedly a domestic case of antitrust immunity with only limited relevance for international airline markets, the results suggest that antitrust immunity can have significant and long-lasting negative effects on competition. 
gateway-to-gateway routes ${ }^{57}$ after receiving antitrust immunity and the thereby triggered downward pressure on price. Interestingly, Willig et al. ${ }^{58}$ are also able to investigate the effects of carve-outs and conclude that they diminish or even eliminate the benefits of antitrust immunity. In particular, the authors show that trips including a carved-out segment have higher fares than trips with no such carve-out. ${ }^{59}$

In a nutshell, it can be concluded that from both theory and empirics the effects of antitrust immunity on market prices are undetermined. The direction of price changes following granting of the antitrust immunity will depend on the specific market characteristics. However, every solid econometric analysis needs to consider the identified potential trade-off of cheaper interline connections and potentially more expensive online connections between the two hubs of the alliance members. In trying to intervene in online markets, regulators need to act consciously in order to avoid destroying efficiencies to the extent that consumers are eventually harmed by market interventions.

\subsubsection{Effects on non-price parameters}

It is a well established fact that price is not the only product characteristic taken into account by consumers in making their choices. Firms therefore also compete in non-price characteristics, and tend to work hard to differentiate their product from those of their competitors, in order to charge a premium for the associated distinguishing features. With respect to passenger airline markets, frequency and convenience of service are arguably the most important (and closely related) non-price features consumers will care about. Higher frequency of service means lower schedule delay, and better scheduling coordination between the partner airlines implies more benefits for the interline passengers via shorter total travel time, other things equal. Airlines also use their frequent flier programs to create horizontal product differentiation via brand loyalty.

The issue of choice of non-price characteristics under airline joint ventures has received limited attention in the literature. ${ }^{60}$ Bilotkach $^{61}$ offers a model which allows a purely complementary alliance to choose prices and the degree of scheduling coordination; Lederman $^{62}$ provides empirical evidence on demand effects of international frequent flier program partnerships. Modeling choice of price and frequency is generally a complex affair. It is hard to predict how interline partnerships will affect individual members' frequency choice beyond the obvious implication that higher traffic due to a joint venture may yield higher frequency of service on spoke-to-hub routes, creating additional benefits to passengers traveling point-to-point on those markets.

57 The increase in demand and capacity respectively on gateway-to-gateway routes following antitrust immunity is clearly identifiable in the respective transatlantic market data. See generally Volodymyr Bilotkach \& Kai Hüschelrath, Airline Alliances, Antitrust Immunity and Market Foreclosure (Working Paper 2010) for a detailed assessment.

58 Willig et al., see above n 55.

59 Another argument for a reduced impact of carve-outs with respect to restoring competition in gateway-togateway markets is brought forward by Reitzes and Moss, see above n 26 at 307, referring to DOJ documentation. They state that code-sharing alliances might have incentives to compete less aggressively in overlapping markets in order to avoid subverting the respective agreements on connecting traffic.

60 In an airline merger context, Dennis W. Carlton, William M. Landes \& Richard A. Posner, Benefits and Costs of Airline Mergers: A Case Study, 11 Bell Journal of Economics 65 (1980) develop a methodology to analyze the respective potential benefits and costs. Interestingly, their analysis of the benefits focuses on product improvement - the superior product created by a merger which increases the amount of single-carrier versus multiple-carrier service. This approach therefore is a nice example of the importance of non-price characteristics in an assessment of competition in the airline industry. The complementary analysis of possible costs of airline mergers - in the form of reduced competition - focuses on the definition of the market and the significance of potential competition.

61 Bilotkach, 2007b, see above n 17.

62 Mara Lederman, Do Enhancements to Loyalty Programs Affect Demand? The Impact of International Frequent Flyer Partnerships on Domestic Airline Demand, 38 RAND Journal of Economics 1134 (2007). 
The issue of frequent flier program partnerships, which go hand in hand with airline alliances, appears much more interesting for at least three reasons. First, where such partnerships are alliance-wide, airlines entering a global alliance may end up sharing frequent flier programs on markets where they compete with each other (e.g., United and US Airways - both Star Alliance members - on the US domestic market). Recent empirical evidence ${ }^{63}$ suggests that such competing partners will reduce their frequency of service as a cost cutting measure in response to an otherwise higher substitutability between their services. Second, there is strong evidence ${ }^{64}$ that airlines flying into airports dominated by their frequent flier program partners are able to get under the umbrella of what is known as the airport dominance effect. For practical purposes this means that frequent flier program partnerships may increase average fares for flying into some important airports. Third and perhaps most important, the scale of alliance-wide frequent flier programs creates an additional potentially important entry barrier. In this respect, we refer not only to the need for any new alliance to attain certain scale to be able to compete with the incumbents. Frequent flier program partnerships within the alliance can create entry barriers on individual airlines' home markets, as new entrant will have to either attain certain scale, or join one of the global alliances. Alternatively, it can, like Ryanair in Europe, decide not offer any loyalty program and to solely rely on attracting customers via lower fares.

\subsection{Specific theories of anticompetitive effects of antitrust immunity}

The probably biggest drawback of the models that have been used in the literature to address effects of airline partnerships is that they tend to focus on benefits of the removal of double marginalization and economies of scope and economies of traffic density on one or several markets, without putting the markets being modeled into a broader context. Given an increasing role of the only three global airline alliances remaining in the industry, and the tendency among (antitrust) authorities to allow more coordination between alliance members, it is crucial to see what we can find in that broader context. Therefore, the following sections concentrate on the derivation of more specific theories of potential anticompetitive effects triggered by antitrust immunity. In particular, three such theories will be developed in greater detail: the potential for market foreclosure, the potential for collusive behavior, and implications of the current alliance market structure for the development of airline networks.

\subsubsection{Potential for market foreclosure}

Market foreclosure involves denying actual or potential competitors access to either an essential input or customers, and thereby preventing them from competing. The tools in the foreclosing firm's toolbox include vertical integration with competitors, refusal to deal, exclusive arrangements, and price discrimination. The possibility of foreclosure in airline partnerships has been suggested in models of Chen and Gayle ${ }^{65}$ and Bilotkach ${ }^{66}$. Both papers effectively model alliances with antitrust immunity and profit sharing. In either model, where an airline can choose from a variety of potential alliance partners, the airline not chosen as a partner is unable to carry its passengers beyond its network. This issue is illustrated in Figure 4.

\footnotetext{
63 Volodymyr Bilotkach, A Framework for Modeling 'Real-Life' Airline Networks, 8 Review of Network Economics 255 (2009).

64 Mara Lederman, Are Frequent Flyer Programs a Cause of the 'Hub Premium', 17 Journal of Economics and Management Strategy 35 (2008).

65 Chen \& Gayle, see above $n 19$.

66 Bilotkach, 2007a, see above n 17.
} 


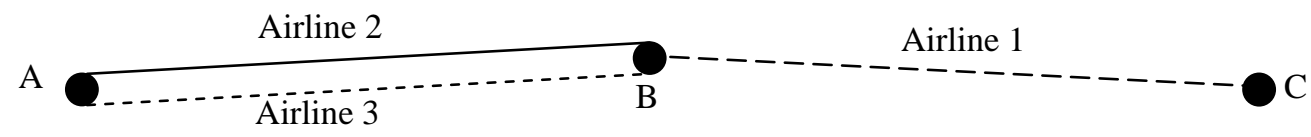

Figure 4. Airline network with choice of alliance partner

As shown in Figure 4, Airline 1 has the possibility to foreclose the A-C market to Airline 3 upon setting up the alliance with Airline 2. To see why and how this can be a rational strategy, suppose that before the creation of the alliance Airline 1 charges the same sub-fare or interlining fee to either Airline 2 or 3. After the partnership between Airlines 1 and 2 is concluded, Airline 1 will decrease the fee for accepting the interline passengers from Airline 2. Airline 1 does not even need to increase the interlining fee for Airline 3 for that carrier to lose its market share, and the change in relative sub-fares or interline fees can already yield foreclosure of the A-C market to Airline 3. In practice, however, foreclosure can also be facilitated either via a direct refusal to deal, or by setting prohibitively high fees for accepting interlining passengers. Doing so might be perfectly rational for the alliance members, as it not only increases their revenue, but also lowers their cost via economies of scope and traffic density (and increases the rivals' cost for the same reason) ${ }^{67}$. Whatever the exact mechanism, the end result will be higher traffic by partner airlines with antitrust immunity and lower traffic by the outside airlines on routes to/from the partner airlines' hub airports. ${ }^{68}$

Empirically, foreclosure will entail non-alliance carriers lowering their traffic from/into an alliance hub, while alliance members would keep increasing this traffic. This point is nicely illustrated in Figure 5, which breaks down the non-stop transatlantic traffic at Frankfurt airport (FRA) by operating carriers' affiliation with the Star Alliance partnerships that enjoy antitrust immunity. We can clearly see that Star Alliance traffic has been increasing over the years, while transatlantic traffic by the airlines outside of Star Alliance has been declining or constant ${ }^{69}$.

67 On the margin, if a connecting passenger comes from within your alliance rather than from the outside, your load factor increases, and that of your rival falls, which - due to economies of traffic density - increases the difference between your per passenger cost and your rival's.

68 See Reitzes \& Moss, see above n 26.

69 Note that while Star Alliance membership has grown over the years; Star Alliance transatlantic services with antitrust immunity to/from Frankfurt airport have been performed by either Lufthansa or United. US Airways, while a member of Star Alliance, has not had antitrust immunity, and therefore its services are included into the 'other airlines' category in Figure 5. 


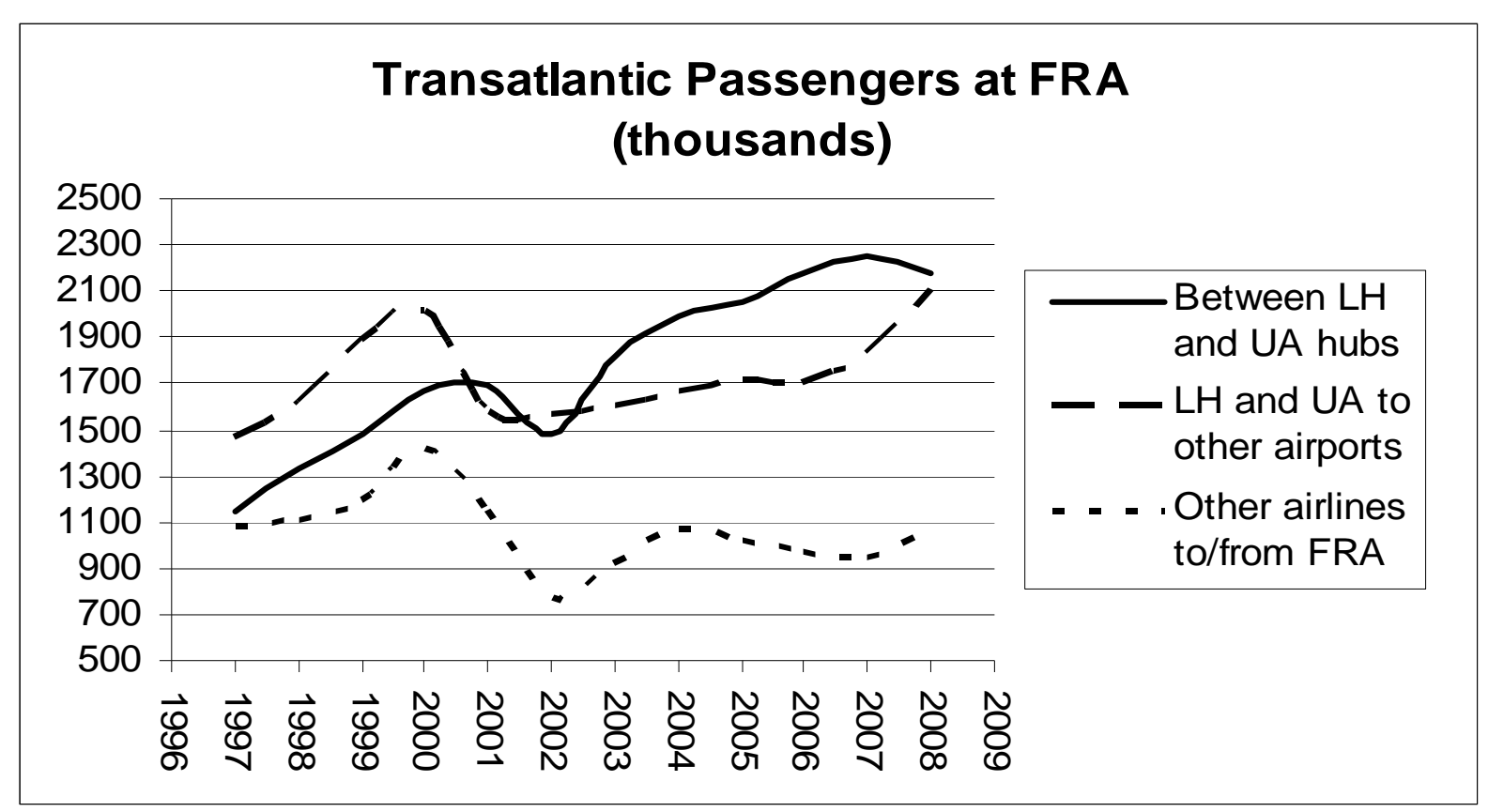

Figure 5. Non-stop transatlantic passenger traffic at Frankfurt Airport

Note: Computed from T-100 dataset of the US DOT (see footnote 41 above). LH = Lufthansa; UA = United; the two airlines had antitrust immunity since 1996. Services between UA and LH hubs include non-stop flights to Washington Dulles, Chicago O’Hare, Denver, and San Francisco by United or Lufthansa.

Generally, as noted by Reitzes and Moss ${ }^{70}$, foreclosure will be more successful the higher the gateway's reliance on connecting traffic and the fewer the options for channeling passengers via alternative hub airports. They further suggest that the current structure of the transatlantic airline industry appears more conducive to foreclosure at EU rather than US gateways, due to the relative dominance of the individual EU countries' flag carriers on the respective domestic markets.

Furthermore, although foreclosure may not reduce overall competition between alliances (as they will still channel their interline passengers via respective hubs, and may not technically exit any city-pair markets), non-stop competition on some important routes may be reduced. This fact is indeed acknowledged by some industry experts ${ }^{71}$, however, they claim that any losses due to foreclosure are more than offset by higher traffic through the alliance members' main hubs. Whether this is so is an empirical question. One thing we can say for sure is that the likelihood of market foreclosure as we described it here is the highest in case of the revenue sharing joint venture (requiring antitrust immunity).

The potentially significant effect of foreclosure on competition in a world with antitrust immunity for airline alliances can also be exemplified in a more complicated airline network with two competing airline alliances. In Figure 6, Airports S1, H1, and H2 are located across the Atlantic Ocean from H3, H4, and S2. Let us call the partnership between the airlines operating hubs $\mathrm{H} 1$ and $\mathrm{H} 3$ Alliance 1, while Alliance 2 members will operate hubs $\mathrm{H} 2$ and H4. Then we can define the following types of markets:

- Markets between the hubs within an Alliance: H1-H3 and H2-H4 routes;

- Markets between the hubs of competing Alliances: H1-H4 and H2-H3;

- $\quad$ Spoke-overseas hub routes: S1-H3, S1-H4, S2-H1, and S2-H2;

- $\quad$ Spoke-spoke routes: S1-S2.

70 Reitzes \& Moss, see above n 26.

71 Daniel Kasper \& Darin Lee, Why Airline Antitrust Immunity Benefits Consumers, GCP: The Antitrust Chronicle, September 2009, 1-5. 


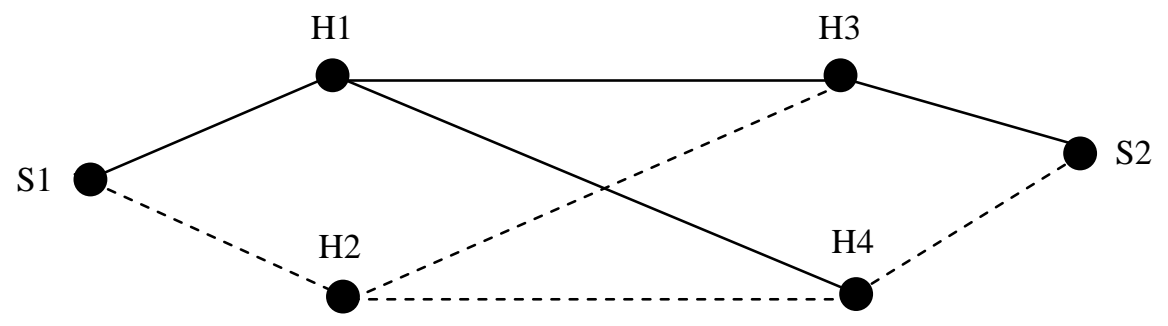

Figure 6. Simple airline network with two alliances

According to the general reasoning above, market foreclosure will yield a reduction in traffic on $\mathrm{H} 1-\mathrm{H} 4$ and $\mathrm{H} 2-\mathrm{H} 3$ routes. Spoke-overseas hubs routes may also be affected. Consider the S1-H3 market. In the extreme case, Alliance 2 may end up closing down the H2-H3 segment of its network (as it is unable to operate this market profitably without passengers connecting to spokes via H3). Even if the segment is not closed down (so that alliance members only reduce frequency of service), the position of Alliance 2 on the S1-H3 route looks less favorable when compared to Alliance 1 . At the same time, the reduction in competition on these routes can be offset by the lower cost; therefore, the net effect on prices is generally uncertain. Spoke-to-spoke markets (S1-S2) are not affected much by the foreclosure, as competition between the airlines is simply replaced by the competition between alliances. It is however true that the S1-S2 passengers will now have fewer options, as routings S1-H1-H4$\mathrm{S} 2$ and S1-H2-H3-S2 are no longer available to them.

The net effect of competition between the alliances is increased specialization of individual alliance members on channeling the passenger traffic via the alliance partners' hubs, and the reduction in traffic to the competing alliance's hub airports. While over the entire network the effect of this network reorganization could be to increase the number of markets served, and competition between the alliances may intensify (especially on the spoke-to-spoke markets), we have identified some markets where competition will likely decrease. Last but not least, not all airlines are alliance members, and the formation of airline alliances puts those carriers into a clearly disadvantageous position, also decreasing competition on the affected markets. As an example, if we suppose that the H3-S2 route is also served by a non-alliance carrier, the formation of the alliance will decrease competition in this market.

Based on this general framework, an empirical investigation by Bilotkach and Hüschelrath ${ }^{72}$ finds that granting antitrust immunity leads to a decrease in flight frequency of up to 6 percent by the non-alliance carriers serving a newly immunized hub. The effect on passenger volumes is even greater (a drop of up to 8.5 percent), suggesting excluded airlines switch to smaller aircraft and/or end up with lower load factors on their services to the newly immunized hubs.

\subsubsection{Potential for collusion}

Generally and ceteris paribus, the potential for collusion among firms or alliances increases with shrinking numbers of competitors as it is easier to reach and maintain a tacitly or overtly formed agreement. The general argument is not new to economic analyses of the airline industry and often studied in direct relation to the theory of multimarket contact.

For example, for the domestic US airline industry there exists substantial evidence consistent with the so-called mutual forbearance hypothesis. This hypothesis states that a firm will be less reluctant to compete aggressively on any given market against the firms with which it also competes on other markets. ${ }^{73}$ An empirical investigation by Evans and

72 Bilotkach \& Hüschelrath, see above n 57.

73 Douglas Bernheim \& Michael Whinston, Multimarket Contact and Collusive Behavior, 21 RAND Journal of Economics 1 (1990) 
Kessides $^{74}$ found that fares are higher in city-pair markets served by carriers with extensive inter-route contacts. The authors argue that the airlines seems to follow a 'golden rule', i.e. that airlines refrain from initiating aggressive pricing actions on a given route for fear that competitors might react in other jointly contested routes. Furthermore, Gayle ${ }^{75}$ investigates the question of whether the effects on price and traffic levels triggered by the approval of the Delta/Continental/Northwest code-share alliance supports collusive behavior hypothesis. Evidence in support of this hypothesis is found on about one third of all relevant markets.

Taking these results for the US domestic airline industry into account, it can be argued that the higher the extent of cooperation within airline alliances, the higher the extent of multimarket contact in the global airline industry. Additionally, the recent inclusion of more than one US airline into the same alliance, along with further consolidation in the US airline industry, certainly has the potential to aggravate the general issue. However, the current literature on airline partnerships does not pay particular attention to the extent of multimarket contact and possible negative effects on competition intensity between the three global alliances.

\subsubsection{Impact on network development}

The issue of the impact of airline partnerships on network development boils down to the question of whether alliances affect any individual airline's incentive to enter with non-stop services. The above discussion on foreclosure suggests that airlines will have less incentive to enter into markets involving hubs of competing alliances. As for entry into other markets, the recent literature suggests both theoretically ${ }^{76}$ and empirically ${ }^{77}$ that an airline will be less likely to enter with a non-stop service on a market where it already is present with a one-stop service. Alliance membership increases the number of such markets, thereby hindering development of individual alliance members' networks. Whether the effect will be the same with or without antitrust immunity is not clear. To the extent we can say partnership with antitrust immunity involves a higher degree of commitment on part of the individual members, we will be able to claim it also hinders entry of the member airlines with new nonstop services.

\section{RECENT POLICY ACTIONS FOCUSING ON ANTITRUST IMMUNITY FOR AIRLINE ALLIANCES}

Based on an initial characterization of the key business motivations for airline alliances and the competitive effects of antitrust immunity, this section aims at presenting the treatment of airline alliances by the responsible authorities as well as other interested parties. Given the focus on transatlantic airline alliances, the analysis concentrates on the recent policy discussions and enforcement actions in the United States and the European Union.

\subsection{United States}

In the following, the general approach and the enforcement actions with respect to airline alliances and antitrust immunity in the United States are discussed.

\subsubsection{General approach}

There are two basic antitrust laws in the United States: The Sherman Act (1890) and the Clayton Act (1914). While the Sherman Act prohibits in Section 1 every contract,

74 William Evans \& Ioannis Kessides, Living by the 'Golden Rule': Multimarket Contact in the U.S. Airline Industry, 109 Quarterly Journal of Economics 341 (1994).

75 Philip Gayle, An Empirical Analysis of the Competitive Effects of the Delta/Continental/Northwest Codeshare Alliance, 51 Journal of Law and Economics 743 (2008).

76 Bilotkach, see above n 63.

77 Abraham Dunn, Do Low-Quality Products Affect High-Quality Entry? Multiproduct Firms and Nonstop Entry in Airline Markets, (Working Paper 2007). 
combination in the form of trust of otherwise, or conspiracy, in restraint of trade or commerce, the Clayton Act identifies specific types of conduct that were believed to threaten competition, such as merger activity. ${ }^{78}$ Both laws are enforceable either by the Antitrust Division of the Department of Justice (DOJ), the Federal Trade Commission, or by each of the 50 state Attorneys General. Additionally, private persons alleging economic injury caused by violation of antitrust laws can bring cases in the US.

Although US antitrust laws are in principle legally binding for every enterprise and individual, federal law or judicial standards give antitrust enforcers several possibilities to prevent or restrain competition in certain industries or sectors. In this respect, the Antitrust Divisions' Manual differentiates between (1) statutory antitrust immunities or exemptions from some or all of the antitrust laws ${ }^{79}$, (2) statutes relating to the regulated industries activities and (3) statutes relating to joint research and development, production and standards development. While statutory antitrust immunities are currently in existence for ten sectors including agriculture, export trade, insurance, labor, professional sports and small business joint ventures, limitations on the full application of antitrust law as a consequence of continued economic regulation are possible in banking, communications, foreign trade, energy and transportation.

Recently, the general discussion on the desirability of exemptions from competition rules was rejuvenated with respect to both the future of antitrust immunity in general, and the future of antitrust immunity for airline alliances in particular. With respect to the former, the final report by the U.S. Antitrust Modernization Commission ${ }^{80}$ recommended that antitrust immunities be granted rarely, and only where, and for so long as, a clear case has been made that the conduct in question would subject the actors to antitrust liability and is necessary to satisfy a specific societal goal that trumps the benefit of a free market to consumers and the U.S. economy in general.

Turning from the general remarks to the airline industry, the Antitrust Division of the DOJ is now - as a consequence of the Airline Deregulation Act of 1978 - responsible for the review of domestic airline mergers and acquisitions. The granting of antitrust immunity to agreements between US and foreign carriers is, however, the responsibility of the US Department of Transportation. ${ }^{81}$ The statutory basis can be found in the 1979 International Air Transportation Competition Act, which allows international inter-carrier agreements to be filed before the DOT for approval and antitrust immunity. ${ }^{82}$ Under the statute, the DOT shall approve such agreements so long as they are 'not adverse to the public interest' ( $\S$ 41309(b)). However, applying the standard test codified in the Clayton Act demands from the DOT that it 'shall disapprove ... an agreement ... that substantially reduces or eliminates competition,' ( $\S 41309(\mathrm{~b})(1)$ ), unless 'the agreement ... is necessary to meet a serious transportation need or to achieve important public benefits (including international comity and foreign policy considerations)' (§ 41309(b)(1)(A)). Receiving the DOT alliance approval is compulsory for a successful application for antitrust immunity, which can be granted 'to the extent necessary to allow [the applicants] to proceed with the transaction specifically approved ... and with any transaction necessarily contemplated by the order' if the DOT 'decides it is required by the public interest.' (§ 41308(b)). Consequently, there are basically two 'public interest' tests bundled in the DOT's alliance approval and immunization procedure. However, the DOT has always recognized that the public interest

78 For a general overview, see Daniel Rubinfeld, Antitrust Policy, in: International Encyclopedia of the Social and Behavioral Sciences, Elsevier Science 553 (2001).

79 See generally Bruce Keiner, Lorraine Halloway \& Gerald Murphy, Airline Alliances, Antitrust Immunity and Mergers in the United States, (Working Paper 2009) for a detailed description of the current statute and the regulatory process.

80 Antitrust Modernization Commission, Report and Recommendations, (Washington D.C. 2007).

81 The DOJ is only allowed to make recommendations.

82 See 49 USC $\S \S 41308-09$. 
standard necessary to receive antitrust immunity is a much more stringent standard than the public interest standard to receive alliance approval. ${ }^{83}$

At first glance, it seems surprising that the US DOT is even considering exemptions from antitrust laws for international airline alliances. No enforcer would seriously think about an allowance to coordinate operations within the US, so a straightforward question is what changes from domestic to international markets in such a way that makes antitrust immunity a (possibly) attractive option for airlines, consumers and politicians? The answer to this key question is multifaceted. Generally, the DOT has used antitrust immunity as an incentive to persuade foreign countries to sign Open Skies agreements with the US. The biggest success in this respect was the Open Aviation Area between the United States and the European Union which came into force on 31 March 2008. The agreement enables any US and EU carriers to fly without restrictions between any airport in the US and the EU and continue flights beyond the US and EU towards third countries ${ }^{84}$. However, Open Skies agreements with countries such as Japan, China or Mexico are yet to be signed, and antitrust immunity remains an important bargaining chip. Furthermore, although the above-mentioned Open Aviation Area is definitely a milestone in transatlantic airline market liberalization; certain regulatory restrictions remain in place. First, the cabotage right is still not granted to the US airlines for destinations within the European Union and vice versa. Second, foreign ownership restrictions remain in place in the US. ${ }^{85}$ In other words, airline operations and airline consolidation remain restricted even in an Open Aviation Area environment, and alliances can be interpreted as the 'next best substitute' to the impossibility of worldwide airline networks operated by a single airline, and the impossibility to coordinate (and therefore rationalize) operations by way of merging two companies.

The general discussions on the desirability of antitrust immunity for international airline alliances are not new. Back in 1999, the Transportation Research Board (TRB) identified that a key argument in granting antitrust immunity to airline alliances is that such partnerships can be appealing to airlines because of the constraints on airline entry and expansion imposed by national governments and embodied in aviation treaties as well as national citizen ownership laws. In accordance to this view, the DOT generally has favored the formation of international alliances, believing that the public will benefit from the network efficiencies, as well as from the new competition, while suffering relatively little from the allied airlines cooperatively setting fares and capacity. Especially in its early approvals, DOT reasoned '... that immunity would enhance competition in international markets by allowing airlines with small market shares to combine their networks and become more effective in competing against larger airlines ${ }^{86}$ This reasoning was the basis for the conditional approval of the KLM/Northwest alliance in $1993 .^{87}$

As noted by Reitzes and Moss $^{88}$ and others - following the surge of immunity applications and subsequent consolidation tendencies - in approving subsequent partnerships, the DOT was basically forced to adapt its justification for granting antitrust immunity to '.. the benefits of creating alliances that could compete against one another, rather than against individual airlines ${ }^{89}$. The concern that granting antitrust immunity to large transatlantic

\footnotetext{
83 See DOT-OST-2008-0234 (Show Cause Order), Order 2009-4-5 (Apr. 7, 2009) at 18.

84 We must however note that we detected only one instance where such authority translated into actual nonstop transatlantic air service. Air France started operating non-stop flights between Los Angeles and London; it eventually withdrew from this market.

85 In the US, foreigners are not allowed to hold more than a 25 percent stake in any carrier operating domestic services.

86 Transportation Research Board, Entry and Competition in the U.S. Airline Industry: Issues and Opportunities, (Washington D.C. 1999) 145.

87 DOT-OST-1995-579-0034 (Final Order), Order 93-1-11 (Jan. 11, 1993).

88 Reitzes \& Moss, see above n 26.

89 Transportation Research Board, see above n 86, at 145.
} 
carriers may cause competition problems on gateway-to-gateway markets was tackled by the US DOT through the imposition of carve-outs. A further concern raised by the TRB is that in advocating international alliances and granting antitrust immunity, DOT might not have given sufficient consideration to the potential effect of international alliances on the competitive structure of the domestic airline industry. Furthermore, the possibility cannot be ruled out that the intent of immunity requests might have been protectionist, producing Open Skies nominally, but with the underlying aim of protecting foreign national carriers from free competition by granting antitrust immunity.

Complementary to the above-discussed general role of antitrust immunity in the US antitrust policy, there have been recent policy discussions questioning whether the granting of antitrust immunity for airline alliances is in the consumers' interest. The latest discussion was triggered in February 2009, when Congressman James L. Oberstar introduced a bill ${ }^{90}$ to study the effects of airline alliances and antitrust immunity on consumers. He argues that the combination of the recent consolidation of airline alliances together with their efforts to extend the scope of their cooperation from code-sharing to the joint planning and pricing of services raises the question of whether the benefits of these alliances to consumers outweigh the adverse effects of the resulting loss of competition. In particular, Oberstar argues that granting of antitrust immunity is a de facto merger of these airlines over the respective routes, and that evidence suggests that the granting of antitrust immunity is followed by a decline in competition from airlines excluded from the alliance. Furthermore, he refers to an unpublished study by The Brattle Group, which finds that immunized airlines have undertaken actions to raise their rivals' costs of interlining at their key hubs. The power of inter-alliance competition is only considered valid for destinations that can be served through more than one hub. If this is not the case, consumers are restricted to choosing services of the 'dominant' alliance. In order to mitigate the potential negative effects, Oberstar proposes to sunset the approval, and to force airlines to reapply for approval. Oberstar's initiative triggered a heated discussion of the pros and cons of antitrust immunity, in which various interest groups participated and partly still participate.

\subsubsection{Enforcement actions}

A first look at the aggregated enforcement data on airline alliances and antitrust immunity provided by the US DOT reveals that the majority of antitrust immunity applications have been approved. Between 1992 an 2009, the US DOT investigated 35 applications for antitrust immunity for the international services of various airline alliances. ${ }^{91}$ Only 3 applications were disapproved $^{92}, 2$ are pending, and 2 applications were dismissed on request by the airlines before a final decision was announced. All of the remaining 28 applications were approved subject to conditions. Excluding the 12 applications of alliances without any involvement of a European carrier leaves 16 successful transatlantic applications for antitrust immunity.

Further analysis of the successful transatlantic antitrust immunity applications leads to two particularly interesting observations. First, the proposed alliances grow over time. While most of the applications until the year 2000 included two airlines, more recent applications include up to 10 unique carriers, all members of the same alliance. Second, there seems to be very limited variation in the general approval conditions over time. The standard approval conditions - which only partly aim at preventing reduced competition - are: (1) Filing of any

90 Statement of the Honorable James L. Oberstar, H.R. 831, A Bill to Ensure Adequate Airline Competition Between the United States and Europe, (3 February 2009, Washington D.C.). Oberstar repeated his concerns in a speech before the International Aviation Club on 23 March 2009.

91 The only domestic airline alliance investigated by the DOT was between Aloha Airlines and Hawaiian Airlines in 2002. See Kamita, above n 56, for an economic analysis of the case.

92 American Airlines - British Airways (1999), American Airlines - British Airways (2002), Delta Air Lines Northwest Airlines - Air France - Alitalia - CSA Czech Airlines - KLM (2006) 
subsequent subsidiary agreements and/or any agreements affecting the alliance; (2) Withdrawal from IATA tariff coordination activities on specific routes; (3) Exclusion of pricing, inventory, yield management and pooling of revenues on specific fares and on specific routes (also known as 'carve-outs'); and (4) O\&D survey data reporting requirement. Additionally, the recent approvals of the DOT also demand (5) yearly reporting requirements from the respective alliance members. The following paragraphs give an overview of selected insights of the more recent investigations of the DOT with respect to SkyTeam, Star and oneworld alliances.

With respect to the SkyTeam Alliance, a landmark investigation out of several applications of members of SkyTeam was the first attempt to receive antitrust immunity for the consolidation of core SkyTeam (Delta/Air France) and Wings (Northwest/KLM) partnerships in 2004. ${ }^{93}$ The investigation was of particular importance for at least two reasons. First, it was the first time that two large airline alliances planned to merge, and members of both alliances applied for antitrust immunity. Second, it was the first time that two US airlines applied for immunity on international markets within the same alliance (although forced to continue competing in the US domestic market). Given the applicants' failure to show that sufficient public benefits would be produced by the agreement, together with the fear that close cooperation on international markets might have spillover effects on US domestic competition, the DOT first denied antitrust immunity for the enlarged SkyTeam alliance. ${ }^{94}$ Anticipating the introduction of the US-EU Open skies agreement, and following the development of a more sophisticated integration concept, SkyTeam members reapplied ${ }^{95}$ for antitrust immunity in 2007, and the DOT (in its Show Cause Order ${ }^{96}$ ) in April 2008 "...tentatively find that the proposed alliance is consistent with the public interest, will produce public benefits, and will not substantially reduce competition” (p.1). In May 2008, the DOT finally decided ${ }^{97}$ to grant six-way antitrust immunity to members of the SkyTeam alliance. Comparing the first and second application for antitrust immunity, the latter especially introduced the concept of 'metal neutrality', ${ }^{98}$ which refers to the practice of revenue and cost pooling within the alliance. Therefore, the identity of the airline operating the flight was not important. ${ }^{99}$ For the DOT, this agreement was essential for the decision to grant antitrust immunity, as only such a merger-like joint venture was likely to generate the operating efficiencies and cost reductions on a significant and sufficient scale.

The core of Star Alliance - United, Lufthansa and SAS - first applied for antitrust immunity in $1996,{ }^{100}$ and was granted immunity in the same year ${ }^{101}$ subject to the standard approval

93 DOT-OST-2004-19214 (Submission, Sept. 24, 2004).

94 DOT-OST-2004-19214 (Final Order), Order 2006-2-1 (Feb. 6, 2006). Other reasons to deny the initial request for antitrust immunity were the potential reduction of competitive pressures in gateway-to-gateway markets and the foreclosure of competitor's access to alliance hubs.

95 DOT-OST-2007-28644 (Submission, Jun. 28, 2007).

96 The following analysis of the decision is largely based on the Show Cause Order (DOT-OST-2007-28644, April 9, 2008) as it provides a much more detailed assessment of the key arguments compared to the relatively brief Final Order. All page numbers of the quotations in the main text in this section refer to the Show Cause Order.

97 DOT-OST-2007-28644 (Final Order), Order 2008-5-32 (May 22, 2008).

98 Granting antitrust immunity as such is seen as not sufficient to reap the identified immunity-specific efficiencies because each carrier still has an incentive to maximize its own revenue. Only a closer cooperation based on metal-neutrality, i.e. an indifference as to which airline actually carries the customer, will allow a full realization of these efficiencies because it removes each carrier's incentive to act opportunistically by increasing its own short-term financial benefit at the expense of the efficiencies delivered by the alliance as a whole. For example, after granting a metal-neutral form of antitrust immunity, every member will focus on winning the customer's business by booking the optimal routing in the entire alliance network. Technically, in a metal-neutral agreement, the participating airlines agree to pool revenues and costs which leads to the indifference which aircraft ('metal') actually operates the flight.

99 See Keiner et al., see above n 79, at 15.

100 DOT-OST-1996-1646 (Submission, Aug. 14, 1996). 
conditions mentioned above. In 2000, 2001 and 2005, a larger Star group - now also including Austrian and Lauda Air (2000) $)^{102}$, bmi (2001) ${ }^{103}$ and Air Canada, LOT Polish Airlines, Swiss International Airlines and TAP Portugal (2005) ${ }^{104}$ - reapplied successfully for antitrust immunity again subject to the standard - albeit adapted - approval conditions. In the decision whether to allow bmi to join Star, approval was given subject to the achievement of an US-UK Open Skies agreement. The latest application ${ }^{105}$ for a further enlargement of Star was submitted to the DOT in 2008 to include Continental into Star Alliance. In July 2009, the already immunized Star Alliance received DOT approval ${ }^{106}$ for the expansion of the alliance to include Continental. ${ }^{107}$ The DOT concluded from its investigation that the inclusion of Continental is in the public interest as it will support increased level of service in international markets and offer the consumers more travel options, shorter travel times, and lower fares. The analysis of the DOT - which again referred to 'metal neutrality' as a cornerstone for the creation of merger-like efficiencies - was separated into markets by region, country-pair, and city-pair, and included assessment of the potential impacts on domestic competition, and the role of inter-alliance competition. In order to preserve competition in all affected markets, the DOT imposed remedies in the form of carve-outs. For the transatlantic market, four new carve-outs were imposed between New York and Copenhagen, Geneva and Stockholm. The two existing carve-outs (Washington-Frankfurt and Chicago-Frankfurt) imposed in the preceding Star investigations were retained until the joint venture is fully implemented. Interestingly, in its initial Show Cause Order, the DOT refrained from demanding carve-outs (for the transatlantic market) as they would prevent the airlines from realizing efficiencies arising from cost savings in 'sales, marketing, and distribution, as well as reductions in operating and fixed costs from incremental traffic flows, higher load factors, common pricing, joint scheduling and route planning, and harmonization of information technology systems" ${ }^{\prime 108}$. However, confronted with the recommendation of the DOJ to deny antitrust immunity to Continental's Star activities entirely (given the expected reduction in competition on nonstop overlap routes, and the fear for facilitating domestic coordination) the DOT decided to accommodate the DOJ with the inclusion of the demanded carve-outs in the final order.

The oneworld Alliance has encountered the most severe problems in its quest for antitrust immunity. In $1997^{109}$ and again in $2001^{110}$, American Airlines and British Airways unsuccessfully applied for antitrust immunity. The general key issue in both applications was the dominant role of both airlines at London's Heathrow airport, and consequently the creation of several highly concentrated transatlantic city-pair markets. Following the introduction of the Open Aviation Area, oneworld reapplied ${ }^{111}$ for immunity in 2008, arguing that new entry possibilities at Heathrow and elsewhere in Europe create a sufficient entry threat to both airlines. On December 21, 2009, the DOJ commented ${ }^{112}$ on the application for antitrust immunity by oneworld, and concluded that the proposed agreement would result in competitive harm on certain transatlantic routes. In particular, the DOJ fears that fares

\footnotetext{
101 DOT-OST-1996-1646 (Final Order), Order 96-11-1 (Nov. 1, 1996).

102 DOT-OST-2000-7828 (Submission, Aug. 18, 2000 and Final Order, Order 2001-1-19, Jan. 26, 2001).

103 DOT-OST-2001-10575 (Submission, Sept. 5, 2001 and Final Order, Order 2002-4-4, Apr. 4, 2002).

104 DOT-OST-2005-22922 (Submission, Nov. 4, 2005 and Final Order, Order 2007-2-16, Feb. 13, 2007).

105 DOT-OST-2008-0234 (Submission, Jul. 23, 2008).

106 DOT-OST-2008-0234 (Final Order), Order 2009-7-10 (Jul. 10, 2009).

107 See generally Benjamin Bradshaw \& Bimal Patel, Final Descent? The Future of Antitrust Immunity in International Aviation, GCP: The Antitrust Chronicle, September 2009(1), 1-8 for a discussion.

108 DOT-OST-2008-0234 (Show Cause Order), Order 2009-4-5 (Apr. 7, 2009) at 12.

109 DOT-OST-1997-2058 (Submission, Jan. 10, 1997 and Final Order, Order 99-7-22, Jul. 30, 1999).

110 DOT-OST-2001-10387 (Submission, Aug. 10, 200 and Final Order, Order 2002-4-4, Apr. 4, 2002).

111 DOT-OST-2008-0252 (Submission, Aug. 14, 2008).

112 DOT-OST-2008-0252 (Comments of the Department of Justice, Dec. 21, 2009).
} 
between six pairs of cities ${ }^{113}$ could increase up to $15 \%$ following granting of antitrust immunity. The DOJ argues that entry is difficult on gateway-to-gateway markets (which contain a separate product market) in general, and at London's Heathrow airport in particular. The DOJ adds that the parties have not shown that the substantial benefits created by the agreement require antitrust immunity, and therefore recommends that DOT imposes conditions such as slot divestitures or carve-outs to heal the identified competition concerns. However, on February 13, 2010, the DOT announced that it has tentatively approved the oneworld Alliance's application for antitrust immunity. ${ }^{114}$ The DOT argues that granting antitrust immunity to the oneworld alliance would provide travellers and shippers with a variety of benefits, including lower fares on more routes, increased services, better schedules, and reduced travel and connection times. The DOT adds that the proposed alliance would enhance competition around the world by creating competition with the existing Star Alliance and the SkyTeam alliance, which already have been granted immunity. However, the Department also notes that the alliance could harm competition on select routes between the United States and London's Heathrow Airport, where the availability of landing and takeoff slots is limited. As a condition of approval, the DOT proposes that the applicants make four pairs of slots available to competitors for new US-Heathrow service. DOT would also require changes to the agreement to ensure capacity growth, and require the carriers to submit traffic data and implement the proposed alliance within 18 months of a final decision.

In a nutshell, as of the time of this writing, two of the three alliances active on the transatlantic market (SkyTeam and Star) have operated with multi-airline antitrust immunity privileges; oneworld alliance have not had similar freedom but will likely be granted antitrust immunity during $2010 .{ }^{115}$ In fact, the market for passenger air travel between the USA and the Continental Europe (excluding the UK) has turned into an effective duopoly.

\subsection{European Union}

In the following, the general approach and the enforcement actions with respect to airline alliances and exemptions from competition rules in the European Union are discussed.

\subsubsection{General approach}

The competition law and policy of the European Union contains four major building blocks: Collusion and Cartels (Article 101 TFEU, ex Article 81 EC Treaty ${ }^{116}$ ), Dominance and Monopoly (Article 102 TFEU, ex Article 82 EC Treaty), Merger Control (Council Regulation 139/2004 EC), and State Aid (Article 107 TFEU, ex Article 87 EC Treaty). While the content of the first three blocks is very comparable to US antitrust law, the fourth block is a unique characteristic of European competition law (given its nature as a collection of independent member states). The enforcement of European competition law has been entrusted to the European Commission, although there have been recent initiatives in the European Union to encourage private parties to bring suits.

Although EC competition law is in principle legally binding for every enterprise, three categories of exemptions to Article 101 TFEU are determined: First, Article 101(3) creates an exemption for practices beneficial to consumers. Second, the Commission has agreed to

113 The city pairs are Boston-London, Chicago-London, Dallas-London, Miami-London, Miami-Madrid and New York-London.

114 DOT Press Release, DOT Proposes Approval of oneworld Antitrust Immunity Application, DOT 28-10 (Feb. 13, 2010).

${ }^{115}$ In fact, in July 2010, the DOT published its Final Order by which it approves a series of agreements establishing an alliance among members of 'oneworld' and grant them antitrust immunity to implement those agreements. See DOT-OST-2008-0252 (Final Order, Order 2010-7-8, Jul. 20, 2010).

${ }^{116}$ Please note the recently introduced new references for the EC Treaty, the now so-called 'Treaty for the Functioning of the European Union' (TFEU). The new Article 101 TFEU is the old Article 81 (ex Article 85) EC Treaty while the new Article 102 is the old Article 82 (ex Article 86) EC Treaty. 
exempt 'Agreements of minor importance' (except those fixing sale prices) from Article 101. Third, the Commission has introduced a collection of block exemptions for different types of contract. The exemption of competition rules for airline alliances is typically related to Article 101(3) TFEU.

Although the economic liberalization of air transport in the European Union was completed in 1997, air transport remains an industry with frequent interventions in addition to the generally applicable competition rules. Examples include air safety regulations as well as environmental and consumer protection standards. ${ }^{117}$ With respect to airline alliances, three regulations are of particular importance. First, Regulation (EEC) No 3975/87 confers powers of the Commission to enforce the competition rules and to adopt block exemptions in the air transport sector. However, until 2004 the Commission did not have specific investigation and enforcement powers to decide on air transport cases involving the European Union and third countries, as the scope of Regulation (EEC) No 3975/87 - defining the rules for the application of EC Competition rules to the air transport sector - is limited to transport services between Community airports. In May 2004, Regulation (EC) No 411/2004 repealed Regulation (EEC) No 3975/87, conferring full investigation and enforcement powers to the Commission.

Second, in May 2004 Regulation (EC) No 1/2003 came into force. This Regulation replaced the mandatory notification and authorization system with a legal exception system. In other words, as part of a broader modernization package, the Commission replaced the old ex ante control of agreements by a regime of ex post control. A key aim of the reform was to refocus the Commission's resources on the most serious restrictions on competition through the reduction of the administrative overload caused by an increasing number of notifications. For the firms, the new Regulation on the one hand provides the freedom to immediately implement agreements. On the other hand, however, it leaves them with the risk that the Commission may open an investigation and eventually - in case the agreement is found to be anticompetitive - issue significant fines. With respect to airline alliances, especially Article 9 of Regulation (EC) No 1/2003 turned out to be of particular relevance as it allows firms after the official opening of an investigation along the lines of Article 7 of Regulation (EC) $1 / 2003$ by the Commission - to agree on binding commitments that lead to the conclusion that there are no longer grounds for action by the Commission. Therefore, given the ex-ante open question of whether a particular alliance agreement is pro- or anticompetitive, the Commission still has to investigate major airline alliances, even in the new system of legal exception.

Third, the most recent legislative action is Council Regulation (EC) No 487/2009 on the application of Article 101(3) TFEU to certain categories of agreements and concerted practices in the air transport sector. The regulation, which came into force in June 2009 and only applies to air transport, specifies that Article 101 (1) TFEU should not apply to certain categories of agreements between undertakings, decisions of associations of undertakings, and concerted practices. In particular, the Regulation refers to joint planning and coordination of airline schedules, consultations on tariffs for the carriage of passengers, baggage, and freight on scheduled air services, joint operations on new less busy scheduled air services, slot allocation at airports, airport scheduling, and the common purchase, development and operation of computer reservation systems. Any regulation shall apply for a specified period only, and may be repealed or amended as soon as decision-relevant circumstances have changed.

117 See generally Nicolas Moussis, Access to European Union, (15 ${ }^{\text {th }}$ edn, Brussels: European Study Service 2006). 


\subsubsection{Enforcement actions}

Between 1994 and 2008, the European Commission investigated 21 cases of proposed airline alliances. However, 10 out of the 21 cases had a solely European focus and are therefore of no particular interest here. ${ }^{118}$ Of the remaining eleven transatlantic alliance applications, final decisions on four (including the three remaining global alliances) are still pending at the time of this writing; two applications became dormant due to DOT's dismissal, two became obsolete as the partnership ended before a decision was made, one application was extended to the current SkyTeam investigation, and one application was cleared without imposing any approval conditions (KLM-Northwest ${ }^{119}$ in 2002). Overall, only one remaining transatlantic alliance was approved subject to conditions (Lufthansa-SAS-United ${ }^{120}$ in 2002). This decision included three types of approval conditions: (1) Withdrawal from IATA tariff coordination activities on specific routes; (2) Surrender and/or release of slots, ground facilities to other airlines; (3) Requirements related to frequent flyer programs, interlining and special prorate agreements with new entrants. If the ten intra-European alliances are added to the sample, there are seven cases in which approval conditions were imposed, and the typical conditions are extended by (4) Restrictions on frequencies/capacity/slots on specific routes/airports, and (5) Requirements related to blocked space agreements with new entrants, and intermodal agreements with land transport companies. Again, there is little variation in the choice of approval combinations over time. However, it is worth noting that approval conditions partly differ from those in the US; especially with respect to the surrender and/or release of airport slots. This can at least partly be explained by the different structures of the respective aviation markets (with a homogeneous country on the one side, and a collection of states with former flag carriers on the other side), along with infrastructure limitations at many large European hub airports.

Based on the short characterization of the aggregated case-specific data, it is worth casting an eye on some key investigations (rather than decisions). The first investigations of transatlantic airline alliances ${ }^{121}$ in the European Union date back to 1996, when the Commission started proceedings under Article 89 EC Treaty in order to examine whether four alliances between European and US airlines ${ }^{122}$ are compatible with EC competition rules. In their publications of the conditions for approving the Lufthansa/SAS/United Airlines and British Airways/American Airlines alliances in July $1998^{123}$, the Commission stated that both alliances require close cooperation covering practically the full range of their activities. Interestingly, while in case of the LH/SAS/UA alliance the Commission only investigated a possible restriction of competition contrary to Article 85 EC Treaty, it extended the investigation in the BA/AA case to Article 86 EC Treaty as well. While the Article 85 competition concern stems from the creation of significant barriers to entry by the alliances, the Article 86 concern refers to the parties' dominant position on hub-to-hub routes. In both cases, the Commission signaled to approve the alliances provided certain conditions are fulfilled. These conditions included the following: First, if requested by a competitor during a

118 See John Balfour, EC Competition Law and Airline Alliances, 10 Journal of Air Transport Management 81 (2004) for an assessment of this set of airline alliances.

119 Commission notice concerning the alliance agreements between KLM Royal Dutch Airlines and Northwest Airlines, Inc. (COMP/D-2/36.111), Official Journal C 117, 15/04/1997, 8-12.

120 Commission notice concerning the alliance between Lufthansa, SAS and United Airlines (2002/C 264/03), Official Journal C264, 30/10/2002, 5-9.

121 An assessment of intra-Community airline alliances is omitted in the following.

122 The alliances were British Airways/American Airlines (1996), Lufthansa/Scandinavian Airlines/United Airlines (1996), KLM/Northwest (1996) and Sabena/Austrian Airlines/Swissair/Delta Airlines (1996).

123 European Commission (1998a), Commission publishes its conditions for approving the Lufthansa/SAS/United Airlines air alliances, IP/98/640, 8 July 1998, Brussels. European Commission (1998b), Commission publishes its conditions for approving the British Airways/American Airlines, IP/98/641, 8 July 1998, Brussels. 
period of six months following authorization of the alliance, alliance members would be required to reduce frequencies on hub-to-hub routes with an annual traffic of at least 120,000 passengers and at least 13 frequencies per week. Second, both decisions obliged the alliance to release slots (without compensation) as soon as a rival airline wishes to launch a new service or expand an existing service and cannot obtain the necessary slots. ${ }^{124}$ Other proposed conditions for both alliances relate to frequent flyer programs, computerized reservation system displays, relations with travel agencies and corporate customers, as well as interlining.

More than four years later, in October 2002, the European Commission decided to close its investigations into the KLM/Northwest and LH/SAS/UA alliances. ${ }^{125}$ With respect to the former alliance, no remedies were imposed, while the latter alliance successfully addressed concerns about reduced competition on a number of hub-to-hub connections by agreeing to surrender slots at Frankfurt airport to allow new air services on the four hub-to-hub routes concerned. Interestingly, in both decisions the Commission accepted the argument by the parties that indirect flights could constitute suitable alternatives to direct flights, and one-stop competition is therefore capable of offsetting the feared significant reduction in competitive pressure due to significant entry barriers at the respective hubs. ${ }^{126}$

Following the founding of the SkyTeam alliance, the Commission launched an investigation in July 2000. In June 2006, the Commission confirmed sending a Statement of Objections to members of SkyTeam (addressed to Aeromexico, Air France, Alitalia, Continental Airlines, CSA, Delta Airlines, KLM, Korean Air Lines and Northwest Airlines). In the statement, the Commission finds that it is very unlikely that cooperation between the parties results in negative effects on competition in most of the several thousand city pairs worldwide. On the contrary, the Commission expects that substantial (consumer) benefits will result from the alliances, such as better connectivity, cost savings, and synergies between the parties. Nevertheless, the Commission identified a number of markets (between the EU and the US, within the EU, as well as between the EU and other third countries) in which the agreement might cause negative effects on competition. This view was repeated in October 2007, when the Commission invited comments from interested parties on commitments proposed by eight members of the SkyTeam alliance. ${ }^{127}$ The parties mainly offered making slots available at appropriate EU airports to allow competitors to operate new or additional services, to share their frequent flier programs, to conclude interlining agreements with new entrants, to enter into special prorate agreements for 'behind and beyond traffic'128 on intraEuropean routes, and to facilitate intermodal services (such as the provision of an itinerary that includes surface transportation). The parties further offered these commitments for five years for US destinations, and for six years for all other city-pairs, and also proposed to

${ }^{124}$ The remedy was proposed for the hubs in Frankfurt and Copenhagen (LH/SAS/UA) and London (BA/AA) and was restricted to a maximum total number of slots to be released to 108 (LH/SAS/UA) and 267 (BA/AA) respectively.

125 European Commission (2002), Commission closes probe into KLM/Northwest and Lufthansa/SAS/United Airlines transatlantic air alliances, IP/02/1569, 29 October 2002, Brussels.

126 The remaining two alliance cases were closed by the Commission. The BA/AA alliance was abandoned twice by the parties after the US Department of Transportation requested the divestiture of 224 slots to heal the competition concerns. The Swissair/Austrian/Delta alliance did not exist in that form at the time of the decision. Delta entered the SkyTeam alliance (together with Air France, Alitalia, CSA, Korean Air and Aer Mexico) for which the Commission launched an investigation in July 2000.

127 European Commission (2007), Antitrust: Commission market tests commitments from eight members of SkyTeam concerning their alliance cooperation, IP/07/1558, 19 October 2007, Brussels. The entire commitments package is available on the following webpage: http://ec.europa.eu/competition/antitrust/cases/decisions/37984/commitments.pdf (visited 7 August 2010).

${ }^{128}$ Following the definition by the European Commission, special prorate agreements are agreements between two or more airlines on the apportionment of through-fares on journeys with two or more legs operated by different airlines. 
establish a trustee to monitor the implementation of the remedies. The investigation is ongoing.

In addition to the ongoing SkyTeam investigation, the European Commission recently also started investigations of the remaining two major airline alliances, aiming at reaching conclusions on the compatibility of the respective partnerships with European rules on restrictive business practices (Article 101 TFEU). ${ }^{129}$ In particular, the European Commission typically notices that the level of cooperation (e.g. jointly managed schedules, capacity, pricing and revenue management on transatlantic routes, as well as revenue sharing and sales of tickets on these routes without preference between these carriers) in question appears far more extensive than the general cooperation between these airlines and other airlines within the respective alliances. The Commission plans to assess to what extent such high degree of coordination may lead to restriction of competition on certain transatlantic routes. However, in its analysis the Commission announced that it will also take any consumer benefit of the airline agreements into account.

In a nutshell, at the time of this writing, no final decision has been reached in any of the three ongoing alliance investigations. Most recently, in October 2009, the Commission confirmed that it has sent out a Statement of Objections ${ }^{130}$ to members of the oneworld alliance, namely British Airways, American Airlines and Iberia. ${ }^{131}$

\section{IDENTIFICATION OF IMPROVEMENT POTENTIAL FOR ASSESSMENTS OF ANTITRUST IMMUNITY}

Given the analysis of the competitive effects of granting antitrust immunity presented in the third section, and the presentation of recent policy actions in the preceding chapter, the consequential final step compares both sets of issues, and indentifies improvement potential for a full-fledged assessment of antitrust immunity for airline alliances.

Starting with a short review of the key insights of both complexes, the analysis of the competitive effects concluded that interline partnerships benefit consumers thanks to the removal of double marginalization, economies of scope and economies of traffic density, as well as operational efficiencies. These benefits might partly come in the form of lower ticket prices, but might also include higher flight frequency, more destinations within easy reach, or shorter travel times. However, cooperation among airlines can also cause significant costs to society, most notably because competition is eliminated on the overlapping parts of the alliance network. Even though the benefits for interline passengers could still be larger, travelers on gateway-to-gateway routes are possibly harmed. However, whether regulatory interventions in the form of carve-outs on the respective routes can generally improve the

${ }^{129}$ European Commission (2009), Antitrust: Commission opens formal proceedings against certain members of Star and oneworld airline alliances, MEMO/09/168, 20 April 2009, Brussels; European Commission (2006), Competition: Commission confirms sending Statement of Objections to members of SkyTeam global airline alliance, MEMO/06/243, 19 June 2006, Brussels.

130 A Statement of Objections is a formal step in Commission antitrust investigations in which the Commission informs the respective parties of the objections raised against them.

131 In July 2010, the European Commission published legally binding commitments offered by British Airways, American Airlines and Iberia. There commitments were offered in response to the Commission's concerns that the planned joint venture may be in breach of EU antitrust rules and harm consumers on transatlantic routes. The commitments include the release of slots at Heathrow airport to allow entry on particular routes (London to New York/Boston/Miami/Dallas) for which competition concerns have been raised. The entire commitments package is available on the following webpage: http://ec.europa.eu/competition/antitrust/cases/dec_docs/ 39596/39596_3244_14.pdf (visited 7 August 2010). Given the finding of the European Commission that the commitments offered by the airlines were suitable to remedy the competition concerns, the investigation has been closed. See European Commission (2010), Antitrust: British Airways, American Airlines and Iberia commitments to ensure competition on transatlantic passenger air transport markets made legally binding, MEMO/10/330 and IP/10/936, 14 July 2010, Brussels. 
situation remains unclear from both theoretical and empirical perspective. While competition might not be fully eliminated in a carve-out set-up, the realization of the full range of efficiencies is partly blocked. Generally, the academic literature is inconclusive on the degree of airline cooperation that maximizes social welfare.

From the perspective of recent policy actions, one key insight of the discussion in the preceding chapter was that airline alliances enjoy a special treatment, either through antitrust immunity in the US, or exemption from competition rules in the EU. The description of the general approach in both jurisdictions showed that economic arguments are only one aspect during the investigation of an airline alliance. Especially with respect to the situation in the US, the fact that the DOT - and not the DOJ - is still responsible for the investigation and the decision on whether to grant antitrust immunity is a clear sign for the significance of political arguments. ${ }^{132}$ Additionally, the analysis of the recent enforcement actions revealed that majority of airline alliances were approved by the DOT, while the investigations in the EU are ongoing. Although the approval conditions imposed by the DOT have not changed significantly over a long period of time, recent case investigations focused to a larger extent on the realization of efficiencies by the alliance members through the promotion of mergerlike cooperation.

Given this broad review of the basic insights of the preceding two chapters, two areas of improvement potential can be identified: institutional aspects and investigatory aspects. While the former category basically asks 'what' is investigated by 'whom', the latter asks 'how' the investigation proceeds. Starting with the institutional aspects in the US, the currently followed general approach makes it hard to identify one key goal that should be followed by the enforcement agency. With respect to antitrust policy generally, most researchers and practitioners would probably agree that the decisions by an antitrust authority should be guided by the concept of consumer welfare. ${ }^{133}$ However, the current presence of two 'public interest' tests ${ }^{134}$ demands an additional assessment of other 'important public benefits' which factually leads to a softening of the assessment criteria, and complicates a clear assessment by the enforcement agency. This key problem is reflected by the fact that the investigatory and decisive powers still lie with the DOT rather than the DOJ. Although this might have been a reasonable step in the times of heavy regulation of international markets, the recent successes with respect to the introduction of Open Aviation Area agreements suggests that competition and therefore competitive effects analysis gained importance. Hence, as the greater expertise and competence for such analyses can be expected in the Antitrust Division of the Department of Justice rather than the Department of Transportation, a step worth considering is switching responsibilities between DOT and DOJ, allowing the DOT to still comment on the respective cases, but leaving the final decision to the DOJ. Extrapolating the most recent recommendations of the DOJ in immunity investigations, such a step is very likely to raise the bar for immunity applicants.

With respect to the EU, there do not seem to be comparable institutional problems - at least since the key issue of missing investigatory and decisive powers of the EC for international cases was removed in 2004. However, airline alliances also enjoy a special status in the EU, creating the problem of blurred investigatory aims as already described for the US above. From a procedural perspective, it became obvious from studying the case history that the EC may need to improve the speed of its investigations. Two final decisions on airline alliances in the last fourteen years must be considered as suboptimal. This is especially problematic for the applicants as they are confronted with significant uncertainty: their

\footnotetext{
132 See Section IV. A. 1. above for a discussion.

133 Even if an agreement on the consumer welfare standard is reached, it is still necessary to further specify the desired set of criteria. In particular, it must be clarified what is understood by consumer welfare and which price- and non-price determinants should enter a possible quantification.

134 See Section IV. A. 1. above.
} 
substantial investments in the respective alliance structure may be worthless if the EC decides to classify them as anti-competitive. Therefore, in a nutshell, while the problem in the US must be seen in the institutional structure that still stems from those early days of economic liberalization; the EU should work on the internal procedures to speed up the investigation process. Although technically Regulation (EC) 1/2003 allows the airlines to immediately implement their alliance plans, they face a significant uncertainty as the Commission may later come to the conclusion that the agreement is anticompetitive. In such cases, the firms do not only have to end the agreement but additionally are subject to substantial fines for their proven infringement of EC competition law.

Turning from the institutional aspects to the investigatory aspects, ${ }^{135}$ the recent immunity investigations in the US provided very detailed economic assessments of many involved parties, which make it hard to believe that any substantial economic argument was missed during these investigations. At the same time, although all relevant arguments might have been brought forward; we cannot rule out the possibility that the DOT evaluated and/or weighted them suboptimally in the preparation of its decisions. This suspicion is supported by the disagreements from DOJ (an agency with much more extensive experience on various aspects of antitrust enforcement as compared to DOT) on some of DOT's decisions. Therefore, the following paragraphs will focus on three particular aspects of an investigation of airline alliances ${ }^{136}$ (assessment of competitive effects, efficiencies, and approval conditions) which might have been underrepresented in past decisions. While developing these arguments, we largely follow the structure of the existing US/EU Horizontal Merger Guidelines, as we believe that contemporary airline alliances with antitrust immunity are factually mergers rather than joint ventures. This viewpoint is supported by antitrust experts, who argue that antitrust assessments of joint ventures and mergers become virtually identical as soon as competition in consumer markets is directly affected (and this condition is certainly fulfilled by airline alliances). The typical joint venture from an antitrust perspective is formed by the companies with complementary resources to pool their research and development efforts. In such joint venture projects not only the created efficiencies are often obvious and undisputed, but also the assessment of competitive effects is often obsolete given the premarket characteristics of the agreements. However, it is rather undisputed in the antitrust literature that as soon as joint venture projects include agreements with respect to product development or even the marketing of the products, an antitrust assessment of such a joint venture becomes virtually identical to that of a merger. ${ }^{137}$

With respect to assessment of the competitive effects, there are basically two separate recommendations. First, investigators need to extent their analysis of possible anticompetitive effects of antitrust immunity to non-price characteristics. Although the effects of changes in the market price on consumer welfare are important, few economists would disagree that other factors such as quality, service or the introduction of new products create significant value for consumers, and therefore need to be integrated into an overall assessment. ${ }^{138}$ With respect to airlines, the discussion in Section III has shown that airline alliances might have significant effects on network development (via possible changes in the

${ }^{135}$ Due to the small number of recent EU decisions on airline alliances, the following paragraphs concentrate on the situation in the US.

${ }^{136}$ Please note that this paper cannot aim at providing a full-fledged antitrust framework for an analysis of airline alliances. Such a framework would need to be constructed along the lines of the existing horizontal and non-horizontal merger guidelines and would have to contain all key steps such as market delineation, assessment of market concentration, assessment of unilateral, exclusionary and coordinated effects, countervailing buyer power, entry, efficiencies, failing firm defense and possible merger remedies.

${ }^{137}$ See generally Gregory Werden, Antitrust Analysis of Joint Ventures: An Overview, 66 Antitrust Law Journal 701 (1998).

${ }^{138}$ For a general discussion, see Kai Hüschelrath \& Nina Leheyda, A Methodology for the Evaluation of Competition Policy, forthcoming European Competition Journal (2010). 
incentives to enter new markets). Such aspects need to be included in an assessment of competitive effects. The same conclusion is true for other non-price parameters, such as flight frequency, schedule coordination, travel times, network size, or frequent flyer programs.

Second, past investigations concentrated to a large degree on studying the unilateral effects of granting antitrust immunity. Although such an analysis is pivotal for any assessment of competitive effects, economists developed more specific theories of how market power can be increased, namely coordinated effects and exclusionary effects theories. With respect to the former, it needs to be assessed whether the remaining competitors have increased incentives and possibilities to tacitly collude, therefore harming consumers. In this respect, the EU Horizontal Merger Guidelines provide a general framework for investigating these aspects. ${ }^{139}$ With respect to airline alliances, the discussion above has shown that although research is sparse, there are some indications that mutual forbearance reduces competitive interaction, (e.g., through membership in the same frequent flyer program), and also affects the incentives of individual airlines to enter new markets.

Complementary to an assessment of coordinated effects, the exclusionary effects of granting antitrust immunity need to be considered as well. Such an assessment basically has to trade-off potentially positive effects of vertical restraints with the negative effects such as raised barriers to entry, foreclosing rivals from distribution channels, or generally impeding effective market integration. Again, the general antitrust literature proposes frameworks for the investigation of such issues. ${ }^{140}$ With respect to airline alliances, the discussion above has suggested the possibilities for airline alliances to foreclose specific markets for other airlines or alliances by implementing a raising rival's costs strategy. One key insight in this respect was that the 'relevant market' for such an analysis needs to be enlarged, e.g., to include the routes between the competitors' hubs.

With respect to an assessment of efficiencies, the antitrust literature on merger efficiencies provides guidance on the key steps of such an analysis. Generally, the major problem for an investigator with respect to merger efficiencies is to check their plausibility, their likelihood of realization, and their likely effects on post-merger competition. ${ }^{141}{ }^{142}$ General empirical evidence on merger efficiencies suggests that the realization of efficiencies often is much

139 The economic literature proposes a multitude of criteria to investigate the relevance and magnitude of coordinated effects in a merger assessment. For example, the EU Horizontal Merger Guidelines identify the following conditions: Reaching terms of coordination, monitoring deviations, deterrent mechanisms, reactions of outsiders, evidence of past coordination and structural features of the market concerned.

140 Thomas Krattenmaker \& Steven Salop, Anticompetitive Exclusion: Raising Rivals' Costs to Achieve Power over Price, 96 Yale Law Journal 209 (1986) identify four conditions to decide whether competition is harmed by foreclosure. First, it must be shown that the ability of the excluded rival(s) to compete is reduced, i.e. the rivals' costs are increased as a direct consequence of foreclosure. Second, it must be shown that market power of the foreclosing firm would actually increase after exclusion and not hindered by, e.g., other powerful (actual or potential) competitors. Third, it must be assessed whether existing rivals may have counterstrategies to protect themselves from the foreclosure attempt, e.g. can switch to alternative sources of supply. Fourth, it must be shown that foreclosure is rational for the dominant firm in the sense that it increases profits. Such an assessment need to show that the lost revenues of the foreclosing firm are more than outweighed by the increased market power and increased profits elsewhere.

141 Based on these general theoretical and empirical considerations together with practical experiences, the following conditions for 'acceptable' merger efficiencies have been identified: 1 . Verifiability - Only those efficiencies will be taken into account, which have a high probability of realization within a reasonably short period after completion of the merger; 2 . Benefit to consumers - Some share of the expected benefits of the merger efficiencies are likely to be passed on to consumers in the form of lower prices; 3 . Merger specificity - The efficiency gains must be merger-specific, that is, they are unlikely to be produced or available absent the merger. Only efficiencies which satisfy all three conditions should be considered during the investigation. See generally ICN, Merger Guidelines Workbook, Prepared for the Fifth Annual ICN Conference (Cape Town 2006).

142 For a detailed assessment, see Kai Hüschelrath, Competition Policy Analysis - An Integrated Approach, (Heidelberg: Physica 2009). 
harder than originally thought pre-merger. For example, a study by Gugler, Mueller, Yurtoglu and Zulehner ${ }^{143}$ finds an efficiency increase in only about one third of all completed mergers, while a bit less than one third experienced an efficiency decrease post-merger.

With respect to airline alliances, the assessment of immunity-specific efficiencies turns out to be the key problem for the investigator. This has basically to do with the blurred knowledge of which degrees of cooperation allow which degrees of efficiencies. ${ }^{144}$ This problem is nicely reflected in the concept of metal neutrality described above, which basically demands that alliance members have to cooperate even more, i.e. they must mimic a merger as closely as possible in order to be granted antitrust immunity. This is somewhat contrary to the question raised in the competitive effects section, namely what is the lowest degree of cooperation to keep the benefits while minimizing the costs. Implicitly, the metal neutrality concept assumes that the efficiency advantages are so substantial that they must dwarf the anticompetitive effects in any case. From the viewpoint of mainstream industrial organization, this assumption is at least discussable given the above-sketched moderate success of companies to realize synergies post-merger. Furthermore, the discussion of the alliance-specificity of efficiency gains needs to be complemented by an investigation into whether these efficiencies are passed on to consumers in the form of lower prices or other non-price advantages.

Finally, with respect to the assessment of approval conditions, the general antitrust literature distinguishes two types of so-called merger remedies: structural and behavioral. Structural remedies aim at changing the allocation of property rights (e.g. full or partial divestitures of products, brands or production plants) while behavioral remedies impose constraints on the merged firms' property rights ${ }^{145}$ (e.g. regulatory-type interventions). From an empirical perspective, an in house-study by the European Commission ${ }^{146}$ showed that while structural remedies are found to be slightly more effective than behavioral remedies, they are often not as effective as assumed at the time of implementation, especially due to composition risks, purchaser risks and asset risks. ${ }^{147}$ This key result is largely confirmed by other studies.

${ }^{143}$ Klaus Gugler, Dennis Mueller, Burcin Yurtoglu and Christine Zulehner, The Effects of Mergers: An International Comparison, 21 International Journal of Industrial Organization 625 (2003).

${ }^{144}$ Volodymyr Bilotkach \& Kai Hüschelrath, Airline Alliance, Antitrust Immunity and Efficiencies (Working Paper 2010) identify four demand-side and three supply-side efficiencies: elimination of double marginalization, expansion of route network, expansion of flight frequency, improved online service options (as demand-side efficiencies) and marginal cost reductions through economies of scope and economies of traffic density, cost reductions through coordination of second-degree competition parameters and cost reductions through coordination of first-degree competition parameters (as supply-side efficiencies). They basically find that for most types, the efficiencies are at least partly immunity-specific. However, the absolute sizes of the effects depend on the actual case under investigation.

${ }^{145}$ Given this initial characterization of merger remedies, the relative advantages and disadvantages of the two respective approaches become apparent. Following Alessandro Tajana, Structural Remedies and Abuse of Dominant Position, (Working Paper 2005), key advantages of structural remedies are their direct effectiveness, their easiness to administer and their limited vulnerability to circumventions. On the downside of structural remedies, problems of incurring unnecessary transaction costs, potential damage caused to innocent third parties and reductions in the incentives to compete vigorously are typically mentioned. Furthermore, fixing structural remedies are regularly risky decisions, as they are largely irreversible once imposed. See generally Massimo Motta, Michele Polo \& Helder Vasconcelos (2002), Merger Remedies in the European Union: An Overview, (Working Paper, 2002). With respect to behavioral remedies, important advantages are their flexibility (which allow ex post fine-tuning) and their ability to take account of existing efficiencies which might be destroyed by a structural remedy. Furthermore, behavioral remedies can be a tool of last resort if, for instance, a structural remedy cannot be implemented; for instance in the case that no buyer for the respective assets can be found. However, high costs of implementation and constant monitoring efforts are additional characteristics of behavioral remedies which must be considered as potential disadvantages of this type of intervention.

${ }^{146}$ European Commission, Merger Remedies Study, (Brussels: DG Competition 2005).

${ }^{147}$ Composition risks basically look at whether the scope of the undertaking is too constrained to attract a potential purchaser. Purchaser risks refer to the possibility that either the purchaser may not be available or 
With respect to airlines, there are certain indications that the imposed merger remedies have not been particularly successful. This is especially mentioned with respect to two structural remedies: slot sacrifices and carve-outs. With respect to the former Adamantopoulos et al. ${ }^{148}$ find that '[s]imply offering slots to allow new entrants to operate on the route(s) where the merger raises concerns has proved insufficient in creating and maintaining competition on these routes and the regulators are looking to solve this." With respect to carve-outs, Section IV above already mentioned the inconclusive theoretical and empirical evidence. The theoretical arguments suggest that carve outs might do more harm than good given the reduced possibilities for the alliance partners to engage in cost-reducing cooperation. In both areas - slot remedies as well as carve-outs - further empirical research is certainly needed to learn more about the effectiveness and efficiency of such remedies.

Given the discussion of selected recommendations for future investigations of antitrust immunity applications, we generally think that - confronted with the significant uncertainties in an ex-ante assessment of the competitive effects of airline alliances in the medium and long run - it is a sensible approach to limit the length of time for which immunity is granted to say five years and to require reapplying at the end of this period. Although the implementation of such a proposal would increase uncertainty for the airlines, it would come with the benefit that airlines - facing the evaluation - have additional incentives to document the created efficiencies and especially to prove that they have passed at least a part of these efficiency advantages on to the consumers.

\section{ConCLUSION}

The market developments in international air transportation have led to the dominance of three global airline alliances - Star, SkyTeam and oneworld. At the same time, members of these alliances receive increasingly more freedom in coordinating various aspects of joint operations, including scheduling and pricing decisions as well as the right to form revenuesharing joint ventures in international markets. Although the significant consumer benefits generated by airline cooperation are undisputed, the recent developments raise antitrust concerns. Against this background, the paper aimed at comparing the key competitive effects of airline alliances and antitrust immunity with the economic lines of reasoning in recent policy actions to develop recommendations for a full-fledged assessment of antitrust immunity for airline alliances.

Our conclusions are the following. First, the frequently postulated lower prices due to removal of double marginalization following antitrust immunity are not obvious from the theoretical point of view, and can be realized within a partnership without such immunity. However, the same conclusion might not be true for certain other types of immunity-specific efficiencies. Second, antitrust immunity might influence non-price characteristics of airline markets (with ambiguous welfare effects). Third, antitrust immunity can inhibit individual partner airlines' network development, facilitate (tacit) collusion and lead to foreclosure of the interline markets for airlines from competing alliances. Fourth, approval conditions such as carve-outs have ambiguous welfare effects as they might keep up competition on overlapping routes but at the same time forecloses the realization of certain immunity-specific efficiencies. Fifth, while in the US the institutional structures behind antitrust immunity investigations should be reformed, the EU has to work on the internal procedures to speed up decision making.

the merging company sells the assets to a weak buyer thereby reducing post-merger competition in the market. Asset risks concern the possible deterioration of the remedies package prior to completion through weakening of the value of assets.

148 Konstantinos Adamantopoulos, Riccardo Croce \& Guillaume Taillandier, Air Transport, in: Global Competition Review, The European Antitrust Review (London, 2010). 
Given this brief summary and referring to our more detailed assessment in the preceding section, we generally conclude that investigations of antitrust immunity applications need to look beyond possible price effects on separate markets, and examine the potential for strategic behavior by the involved airlines. However, confronted with the significant uncertainties in an ex-ante assessment of the competitive effects of airline alliances in the medium and long run it is a sensible approach to limit the length of time for which immunity is granted to say 5 years and to require reapplying at the end of this period. Although the implementation of such a proposal would increase uncertainty for the airlines, it would come with the benefit that airlines - facing the evaluation - have additional incentives to document the created efficiencies and especially to prove that they have passed at least a part of these efficiency advantages on to the consumers. In the meantime, more econometric work is certainly needed to get a better picture of the net welfare effect of contemporary airline alliances in the transatlantic market to base policy decisions on more robust foundations. 